University of St. Thomas, Minnesota

UST Research Online

2015

Internal Corporate Governance: The Role of Residual Income on Divisional Allocation of Funds

Dobrina G. Georgieva

University of St. Thomas, geor0116@stthomas.edu

Follow this and additional works at: https://ir.stthomas.edu/ocbfincpub

Part of the Finance and Financial Management Commons

This Article is brought to you for free and open access by the Finance at UST Research Online. It has been accepted for inclusion in Finance Faculty Publications by an authorized administrator of UST Research Online. For more information, please contact asle4660@stthomas.edu. 


\title{
Internal Corporate Governance: The Role of Residual Income in Divisional Allocation of Funds
}

\author{
Dobrina Georgieva \\ University of St. Thomas, Minnesota
}

\begin{abstract}
:
Internal capital markets of diversified firms have been associated with inefficient allocation of investment funds across divisions, leading to value losses. Utilizing a sample of diversified firms that adopted or eliminated Residual Income (RI) plans between 1990 and 2009, we show that adoptions of these plans mitigate investment distortions and lead to value gains. Following the adoption of RI plans, diversified firms start allocating investment funds based on growth opportunities of their divisions. RI plan adopters lower their divisional investment levels, especially in segments with below-average growth opportunities. The overall investment allocation efficiency improves, and the diversification discount diminishes after the adoption of RI plans. However, RI plans appear to be used only as temporary tools for assessing corporate performance. The plans are adopted primarily by firms expected to immediately generate plan bonuses for management, and they are frequently eliminated by firms with bad accounting performance, and low managerial bonuses. The study contributes to the literature on organizational efficiency, internal capital markets and on the importance of measures based on economic profits or residual income.
\end{abstract}

Keywords: Internal capital markets; Residual Income; Diversification; Investment efficiency

JEL classification: G32, G34 


\title{
Internal Corporate Governance: The Role of Residual Income in Divisional Allocation of Funds
}

\begin{abstract}
:
Internal capital markets of diversified firms have been associated with inefficient allocation of investment funds across divisions, leading to value losses. Utilizing a sample of diversified firms that adopted or eliminated Residual Income (RI) plans between 1990 and 2009, we show that adoptions of these plans mitigate investment distortions and lead to value gains. Following the adoption of RI plans, diversified firms start allocating investment funds based on growth opportunities of their divisions. RI plan adopters lower their divisional investment levels, especially in segments with below-average growth opportunities. The overall investment allocation efficiency improves, and the diversification discount diminishes after the adoption of RI plans. However, RI plans appear to be used only as temporary tools for assessing corporate performance. The plans are adopted primarily by firms expected to immediately generate plan bonuses for management, and they are frequently eliminated by firms with bad accounting performance, and low managerial bonuses. The study contributes to the literature on organizational efficiency, internal capital markets and on the importance of measures based on economic profits or residual income.
\end{abstract}

Keywords: Residual income, internal capital markets, diversification, investment efficiency 


\section{Internal Corporate Governance: The Role of Residual Income in Divisional Allocation of Funds}

\section{Introduction}

The purpose of this paper is to study the use of Residual Income (RI) as an incentive mechanism and its role in divisional allocation of funds. Previous research suggests that RI plans have the potential to improve the internal capital allocation process (e.g. Dutta and Fan, 2009; Baldenius et al., 2007). These plans reward managers only if their earnings exceed a charge for the capital they employ, since Residual Income is defined as Earnings minus Capital Cost*Invested Capital. RI plans are expected not only to reward profits, but also to penalize one of the most crucial sources of losses for diversified firms overinvestment in unprofitable divisions (Ozbas and Scharfstein, 2011; Rajan et al., 2000; Berger and Ofek, 1995). Capital charges in the plan formulas can diminish managerial rent-seeking and politicking for extra investment regardless of project profitability, especially since capital charges are division-specific (more risky divisions can be charged higher cost of capital), and increase with invested capital.

The inefficiencies of multi-divisional firms have been attributed to opportunistic behavior of divisional managers, arising due to informational asymmetry between divisions and headquarters (Jensen and Meckling, 1992). These problems are compounded by the difficulties in assessing divisional performance when there are differences in divisional risk and capital use. So far, research on the impact of divisional incentives and on measuring of divisional performance is limited and mainly related to issues of accounting divisional disclosure (e.g. Bens et al., 2011; Berger and Hann, 2007; Bouwens and van Lent, 2007; Chen and Zhang, 2007, 2003; Keating, 1997). ${ }^{1}$ We expect that since RI plans are designed to measure and reward divisional performance, they can be particularly beneficial to multi-divisional firms, and our findings can document the link between residual income use and performance improvements.

Internal capital markets are supposed to help undertake profitable investments that would not have been funded by external capital markets. ${ }^{2}$ However, internal capital markets may fail to allocate capital

\footnotetext{
${ }^{1}$ On the other hand, there is considerable work on the effectiveness of compensation incentives for firm-wide performance (e.g., Core et al., 1999; Mehran, 1995; Jensen and Murphy, 1990).

${ }^{2}$ See Arya and Mittendorf (2011), Gopalan and Xie (2011), Beneish et al. (2008), Borghesi et al. (2007), Fluck and
} 
properly. Ozbas and Scharfstein (2011), Shin and Stulz (1998) and Rajan et al. (2000) empirically document that poorer performing, low growth opportunity segments (i.e., divisions; both terms will be used interchangeably throughout the paper) of diversified firms inefficiently attract extra investment funds at the expense of more profitable, faster growing segments. These outcomes are the result of a variety of investment distortions such as intensified agency problems (Laeven and Levine, 2007, Bernardo et al. 2007), CEO private benefit consumption (Datta et al. 2009), rent-seeking behavior of divisional managers (Rajan et al., 2000; Scharfstein and Stein, 2000), their relative influence (Cremers et al., 2011), CEO's attempts to appease divisions unrelated to her experience with extra capital allocations (Xuan, 2009), disproportionate focus on the performance of newly acquired units (Schoar, 2002). The above valuedestroying behaviors may explain why diversified firms sell at a "diversification discount" of about $15 \%$ compared to the values of their divisions as stand-alone units (e.g., Hoechle et al., 2012; Dos Santos et al., 2008; Berger and Ofek, 1995). In turn, increases in focus are rewarded with higher share prices (Daley et al, 1997; Comment and Jarrell, 1995; John and Ofek, 1995), and are accompanied by more efficient investment decisions (Chen, 2006; Ahn and Denis, 2004; Dittmar and Shivdasani, 2003; Burch and Nanda, 2003; Gertner et al., 2002).

Despite apparent inefficiencies, diversified firms as a form of organizational structure survive and often thrive in today's economy. Rajan et al. (2000) find that $40 \%$ of diversified firms trade at a diversification premium. Consequently, firms apparently possess mechanisms that mitigate the problems of internal capital markets and facilitate synergies from a diversified organizational structure. Indeed, previous work has attempted to look for such corrective tools. For example, Datta et al. (2009) document that stock grants may motivate managers to make better internal capital allocations. Lin et al. (2007) show that active corporate risk management can lower information asymmetries that cause diversification losses. On the other hand, many traditional governance and monitoring mechanisms fail to work properly in multi-

Lynch (1999), Stein (1997), and Gertner et al. (1994) for discussion of the benefits of internal capital markets, diversification, and cross-subsidization. 
divisional firms. Most importantly, bonuses based on company-wide performance and stock options may not be appropriate incentive mechanisms as they hinder assessment of relative contribution of a single divisional manager toward value creation by the whole firm (Keating, 1997). ${ }^{3}$

Despite the potential benefits, some studies question whether RI plans create value (Biddle et al., 1997; Dechow, 1997). In addition, RI plan adoption has some risks for diversified firms. Internal capital markets may be adversely affected by adoption of these plans if they exacerbate the tension between seeking greater individual business unit efficiency versus collaborating for firm-wide synergies. The plans can lead the manager to be too narrowly focused solely on her own projects, with damaging consequences for the firm as a whole. Thus, RI plans can introduce a new form of politicking, as managers avoid cooperation and expend effort in passing off shared costs and assets. Therefore, the main hypothesis tested in this paper is the empirical question whether RI plans improve allocation efficiency of the internal capital markets in a diversified firm, and whether they add value to the firm as a whole.

Based on a sample of 89 diversified firms that adopted RI plans between 1990 and 2001, with follow-up until 2009 for possible plan elimination, our main results are:

1) RI plan adoptions lead to significant performance improvements for diversified firms, but not for single-segment (i.e., focused) companies.

2) For diversified firms, segment-level investment after the adoption of the RI plan is significantly positively related to segment-level growth opportunities (while the investment was unrelated to segment-level growth opportunities before the plan was adopted). RI plan adopters also reduce their investment, especially in segments with below-average growth opportunities.

3) The overall efficiency of investment by diversified RI plan adopters significantly improves during the post-adoption period. In addition, while overall investment efficiency was negatively related to the dispersion of divisional growth opportunities before RI plan adoption (similarly to Rajan et al., 2000), post-adoption investment efficiency is less affected by the dispersion of divisional growth opportunities.

4) After RI plan adoption, diversification discounts of multi-divisional adopters shrink compared to the discounts of similarly diversified non-adopters. Diversification discount reduction is linked to the increase in overall investment allocation efficiency and to the reduction of the negative impact of dispersion of divisional growth opportunities during the post-adoption period.

Arguably, firms adopt RI plans because they find such plans advantageous compared to the

\footnotetext{
${ }^{3}$ In addition, Ahn et al. (2006) show that diversified companies cannot rely on the monitoring role of debt due to managerial discretion to suboptimally allocate debt across divisions. Berry et al. (2006) imply that CEOs of multisegment firms are less likely to be replaced following poor performance.
} 
alternative "traditional" compensation plans (stock options, bonuses). We find that RI plans are primarily implemented by large diversified firms that can benefit from post-adoption improved efficiency of internal capital market. The large firms could also absorb the potentially high expenditures related to adoption. ${ }^{4}$ In addition, we find that firms appear to implement such plans mainly if management gains by adoption. Adopters are more profitable, have lower levels of cash reserves (i.e., assets that are less likely to beat cost of capital targets), and invest less. At the same time, RI plans are frequently dropped by firms whose managers likely no longer gain from the plans - companies with bad accounting performance, low managerial bonuses, and high cash reserves. Ultimately, our evidence is consistent with RI plans being a valuable, but only temporary tool for measuring firm performance and affecting managerial incentives.

It is difficult to distinguish between well-performing firms that adopt RI plans, and firms that perform well because they adopted those plans. In order to capture the endogeneity of plan adoptions, we repeat the analysis for subsamples of "expected adopters" (adopters expected to implement RI plans) vs. "unexpected non-adopters" (firms that do not adopt RI plans despite being expected to do so). Investment allocation improvements and value gains remain significant (and generally increase) for the "expected adopters", suggesting that the adoption of such plans directly leads to the better performance. We also find that CEO turnovers are not significantly related to investment efficiency or value changes in RI plan adopting firms. In addition, the RI plans were not likely triggered by takeover threats, as no adopters were targeted for acquisition during the three years before the adoption.

Overall, the findings of our study suggest that RI plan adoption mitigates deficiencies of internal capital markets and improves organizational efficiency. Diversified adopters realize investment efficiency improvements and value gains. Furthermore, the finding that RI plans help primarily diversified (but not focused) firms is consistent with the argument that the plans are beneficial primarily because they are a

\footnotetext{
${ }^{4}$ The costs may include not only direct fees paid to consulting companies typically hired to assist with plan adoption, but also the opportunity costs associated with actual implementation, setting the parameters affecting RI plan values, training of managers to understand plan consequences and implications, etc. Consulting company Stern Stewart \& Co. (that implements RI plans under the name "Economic Value Added") claims it uses approximately 160 adjustments for converting accounting profit into economic profit in order to implement RI plans. O'Byrne and Young (2009) point to this complexity as the reason why RI plans are not more common.
} 
segment-specific (i.e., allowing for unique segment risk-related hurdle rates) RI mechanism for measuring performance. RI plans affect the CEO, top executives and all divisional managers, not just a subset. In addition, the bonuses based on the performance of a particular divisional head are primarily affected by the residual income earned by his/her division, while considering the unique divisional risks. So, our results support research documenting the importance of RI-based measures (e.g., Barniv et al., 2009; Dutta and Fan, 2009; Dutta and Reichelstein, 2005; Hogan and Lewis, 2005), and segment-specific hurdle rates in particular (e.g., Baldenius et al., 2007).

The rest of the paper is organized as follows. In the next section, we formulate hypotheses regarding the impact of plan adoption on functioning of internal capital markets. In Section III, we describe our data. The analysis and findings are presented in Section IV. Section V concludes.

\section{Impact of RI plan adoption on investment, allocation efficiency, and value gains associated with internal capital markets}

\subsection{Advantages and disadvantages of RI plan adoptions}

The concept of Residual Income has been made operational since the 1950s. Recently, however, it has gained greater acceptance as consulting firms such as Stern Stewart (who refer to it as EVA ${ }^{\mathrm{TM}}$, Economic Value Added), Boston Consulting Group, and KPMG have advocated its use. Economic profits are conceptually tied to the widely-accepted NPV rule. They measure firm performance by comparing actual profits to required profits, which depend on the capital employed and the risks to which the capital is subjected to. The more risky firm's business is, and the more capital it uses, the greater the profits the manager must generate to create positive "economic profit."

Garvey and Milbourn (2000) argue economic profits have an information content going beyond that of prices and accounting profits, and integrating RI plans into factors affecting managerial compensation improves efficiency of incentive contracts. In addition, practitioners have for long linked the use of economic profit to value creation (e.g., Desai et al., 2003; Riceman et al., 2002; Milano, 2000; Ehrbar and Stewart, 1999, Bacidore et al., 1997; O’Byrne, 1996). Hogan and Lewis (2005) test advantages of RI 
plans by studying post-adoption performance of a sample of 108 companies that adopted such plans from 1983 to 1996. Adopters experience reduction in invested capital and improvements in operating performance, but performance gains are similar to those experienced by matching firms. Significant postadoption differences appear only after the authors restrict their analysis to subsamples of expected adopters (based on pre-adoption performance, compensation structure, and financing) in comparison to firms that were expected to adopt RI plans but chose not to do so.

RI plans also have critics. While Wallace (1997) shows that managers compensated based on RI plans indeed reach the plan targets, Fernandez (2001) argues that the plan levels are poor predictors of market value. Biddle et al. (1997) document that the plan changes are worse predictors of stock returns compared to earnings, Dechow et al. (1999) argue that RI-based valuation models provide only minor improvements over models based on discounted dividends, and Barniv et al. (2009) show a negative relation between analyst recommendations and residual income. RI plans are argued to create excessive focus on short-term profitability, and blamed for rushed asset sales and layoffs as managers attempt to reduce capital charges. These plans have also been criticized as difficult to apply due to their complexity and many adjustments (e.g., O’Byrne and Young, 2009). Consequently, some adopters tend to implement simplified versions of RI plans that do not conform to the theory (Weaver, 2001).

Overall, existing research on RI plan adoption benefits offers mixed conclusions. Most importantly, to our knowledge, the impact of RI plan adoption on internal capital markets has not been studied yet. Our study should also complement the research on the efficiency of residual income measures (e.g. Barniv et al., 2009; Hogan and Lewis, 2005) and segment-specific hurdle rates in particular (e.g. Baldenius et al., 2007).

\subsection{Advantages and drawbacks of organizational structures based on internal capital markets}

Since the boom of conglomerate diversifications in 1950's, previous research has recognized benefits of internal markets. Early studies argued that these markets allocate resources more efficiently compared to free (external) markets (Weston, 1970). Internal capital markets were claimed to facilitate adoption of profitable investments that would not have been funded by external capital markets, arguably 
due to information asymmetry between company insiders and outside investors (Gertner et al., 1994; Fluck and Lynch, 1999), as well as agency costs of financing (Stulz, 1990). Lewellen (1971) argued that diversified companies generate larger tax savings due to greater debt capacity. Majd and Myers (1987) also predict tax savings due to diversified firm's ability to net profits and losses of different divisions. Borghesi et al. (2007) show that mature firms in stagnant industries gain by diversification. Gopalan and Xie (2011) and Yan et al. (2010) document easier access to external and internal capital by diversified firms in tightened market conditions or distress.

More recently, research has focused on the analysis of internal capital market deficiencies. Internal capital markets tend to allocate capital suboptimally compared to the external markets. Ozbas and Scharfstein (2011) show that segment investment in diversified firms is insensitive to segment growth opportunities. This failure is primarily due to agency costs (Laeven and Levine, 2007), as well as costly information asymmetry between CEO and divisions (Jensen and Meckling, 2009, 1992) resulting in a variety of investment distortions. Worse-performing divisions may attract extra investment funds at the expense of their better performing counterparts thanks to divisional managers' rent-seeking behavior aimed at receiving higher compensation (Scharfstein and Stein, 2000), and their tendency to finance defensive inexpropriable divisional investments (Rajan et al., 2000). Cremers et al. (2011) indeed document that more influential divisional managers receive more investment funds. Many of the inefficiencies can be directly attributed to CEO actions such as private benefit consumption (Datta et al., 2009), inefficient postsuccession (Xuan, 2009) and post-acquisition (Schoar, 2002) behavior.

The monitoring mechanism failures and investment deficiencies may explain findings of Berger and Ofek (1995) that diversified companies sell at a "diversification discount" as high as 15\% with respect to the value of divisional assets as self-standing entities. ${ }^{5}$ Focus-increasing corporate events are also

\footnotetext{
${ }^{5}$ Diversification discounts were also documented by Hoechle et al. (2012) and Servaes (1996) for U.S. firms, by Schmid and Walter (2009) for financial institutions, and by Dos Santos et al. (2008), Fauver et al. (2003) and Lins and Servaes (1999) for international firms. The magnitude of diversification discounts was challenged by e.g., Villalonga (2004), Campa and Kedia (2002), and Graham et al. (2002) whose studies utilize econometric techniques that take into consideration endogenous choice of firm diversification. However, Hoechle et al. (2012), Ahn and Denis (2004),
} 
typically accompanied by positive stock price reactions (Daley et al., 1997; Comment and Jarrell, 1995, John and Ofek, 1995) and more efficient investment allocation (Chen, 2006; Ahn and Denis, 2004; Burch and Nanda, 2003; Dittmar and Shivdasani, 2003; and Gertner et al., 2002).

Rajan et al. (2000) provide both the theoretical model and empirical test of company-wide investment allocation efficiency. They measure allocation efficiency (called "the relative value added by allocation." in their paper) as:

$$
\text { Allocation Efficiency }=\frac{\sum_{j=1}^{n} B A_{j}\left(q_{j}-\bar{q}\right)\left(\frac{I_{j}}{B A_{j}}-\frac{I_{j}^{s s}}{B A_{j}^{s s}}-\sum_{k=1}^{n} w_{k}\left(\frac{I_{k}}{B A_{k}}-\frac{I_{k}^{s s}}{B A_{k}^{s s}}\right)\right)}{B A}
$$

where $I_{j}$ refers to capital expenditures of division $j, B A_{j}$ to its assets, $w_{j}$ to its asset weight, and $q_{j}$ to its growth opportunities (measured by the median ratio of market-to-book value of assets of all the singlesegment firms operating in the same industry as division $j$ ). Term $\bar{q}$ denotes average of segment $q$ 's for the company, and the ratio $I_{j}^{s s} / B A_{j}^{s s}$ refers to the median capital expenditures-to-assets ratio for all the singlesegment firms operating in the same industry as division $j$. Term $B A$ stands for company's total book value of assets. Ultimately, Investment Allocation efficiency increases (and more relative value is added) if segments with better growth opportunities receive more capital and vice versa. Rajan et al. (2000) show that Allocation Efficiency is negatively affected by the segment diversity of divisional growth opportunities, measured as the ratio of the firm's standard deviation of segment asset-weighted $q$ 's to the equally-weighted average $q$ of firm's segments:

$$
\text { Segment Diversity }=\sqrt{\sum_{j=1}^{n} \frac{\left(w_{j} q_{j}-\overline{w q}\right)^{2}}{n-1}} /\left(\frac{1}{n} \sum_{j=1}^{n} q_{j}\right)
$$

Finally, Rajan et al. (2000) document that the allocation efficiency and diversity measures have value implication for diversified firms - higher Allocation Efficiency (Segment Diversity) leads to diversification

and Rajan et al. (2000) show that the diversification discount is positively related to the magnitude of investment distortions even after the econometric techniques recognizing endogeneity of diversification choices are applied. Diversification discounts thus can still measure cross-sectional value differences among diversified firms. 
premiums (discounts) in multi-divisional companies.

\subsection{Testable hypotheses for the impact of RI plan adoptions on internal capital markets}

RI plans allow adopters to create unique division-specific profit targets reflecting the riskiness of each particular division, while making each divisional manager primarily responsible for the performance of her division. The ultimate effect of plan adoption may be positive as the adoption likely forces divisions with less growth opportunities to refuse extra capital, in order not to increase their profit targets. Similarly, high growth segments should attract extra investment funds in order to utilize their greater profit potential. However, adopters may also face extra costs and losses. RI plan adoption may force managers to be too narrowly focused on the performance of their own division, disregard company-wide value-enhancing projects, and engage in campaigning to pass off shared costs and assets. Therefore, the ultimate impact of plan adoption is an empirical question:

H1 [H1a]: RI plan adoptions lead to performance improvement [deterioration] for diversified firms.

If plan adoption improves performance of diversified firms, then one should observe more efficient allocation decisions made on divisional levels. Because overinvestment has been identified as one of the sources of value losses in multi-divisional firms, we expect plan adopters to decrease their capital spending. Also, we anticipate increase in the sensitivity of segment investment to segment growth opportunities (measured by segment $q$ ), since Ozbas and Scharfstein (2011) show such increase is associated with improvements in investment efficiency. Thus:

H2 [H2a]: If RI plan adoption is value-enhancing [value-reducing], then divisional investment efficiency improves [worsens] after plan adoption by a diversified firm. Adopters lower [do not lower] their divisional capital expenditures, and sensitivity of segment investment to segment q rises [does not rise].

Improvements in investment efficiency on segment level should lead to the overall increase in company-wide Allocation Efficiency. In addition, if RI plans mitigate divisional inefficiencies, we also anticipate that the negative effect of dispersion of segment growth opportunities on Allocation Efficiency (Rajan et al., 2000) should diminish after the adoption. The opposite should be expected if plan implementation does not lead to improvements in investment efficiency. Consequently:

H3 [H3a]: If RI plan adoption is value-enhancing [value-reducing] for diversified firms, then the 
company's Allocation Efficiency improves [does not improve] after plan adoption. The negative impact of Segment Dispersion on Allocation Efficiency of adopters should [should not] be significantly smaller in absolute value after the adoption, compared to the pre-adoption period.

Ultimately, more efficient decisions should diminish the diversification discount of plan adopters.

In addition, if plans mitigate divisional inefficiencies, the negative effect of dispersion of segment growth

opportunities on diversification discount (Rajan et al., 2000) should be smaller during the post-adoption

period. We should expect the opposite if plan adoption does not improve investment decisions:

H4 [H4a]: If RI plan adoption is value-enhancing [value-reducing] for diversified firms, adopters should [should not] be valued at a smaller diversification discount during the post-adoption period compared to similarly diversified firms. The diversification discount reduction should [should not] be positively related to the improvements in Allocation Efficiency achieved by the adopters. The negative impact of Segment Dispersion on diversification discount of adopters should [should not] be significantly smaller in absolute value after the adoption, compared to the pre-adoption period.

\section{Data}

Our sample of diversified RI plan adopters was constructed from two sources: First, we ran a full text search on 2002, 1999, and 1996 electronic Thomson Research collections of firm proxy statements, and searched for the following keywords: "Residual Income", "Economic Value Added", "Economic Profit", and "Market Value Added". We manually checked all filings and retained only firms where the keyword appeared in the section discussing executive compensation methods, and signaled that the RI plan was indeed used as a primary method of measuring managerial performance. ${ }^{6}$ We then searched for the earliest proxy statement mentioning the keyword, and retained the firm in our sample if this earliest proxy was dated after 1992 (the first year the SEC consistently collected electronic proxy statements). Second, to append our sample with firms adopting RI plans before 1993, we added adopters identified by Hogan and Lewis (2005) who utilize a keyword search similar to ours in proxy statements on LEXIS/NEXIS database

\footnotetext{
${ }^{6}$ We were able to identify another set of 91 diversified firms where some RI plan keyword was mentioned, but the plan was likely not truly implemented. Typically, the keyword occurred near the end of a long list of factors (based on accounting and stock variables, as well as subjective measures) that the company may use to measure managerial performance. In an unreported analysis, we found these "secondary" adopters were not associated with any significant changes in investment allocation efficiency, value (Tobin's Q), or diversification discount following the year of the first occurrence of the keyword in the proxy statement. These results suggest that market does not re-value companies after mere mentioning of a RI keyword in their financial statements. Meaningful implementation of a RI plan is likely necessary for efficiency and valuation gains to materialize.
} 
during the 1983-1996 period. Finally, the sample adopters had to report more than one industry segment on Compustat Segment File in the year of plan adoption.

Each of our sample adopters was assigned a matching non-adopting firm based on (a) diversification status (matching firms had to report more than one industry segment on Compustat Segment File in the year of plan adoption) (b) sales-based Herfindahl Index (an inverse measure of diversification equal to the sum of squared divisional proportions of firm's sales) and (c) asset size. First, we looked for a matching firm with the closest sales-based Herfindahl index, with the same 2-digit SIC and asset size within $50 \%$ and $200 \%$ of that of the sample firm. If we could not find any candidates, we searched for companies based on 1-digit SIC and asset size within 50\% and $200 \%$ of that of the sample firm. If a matching firm still could not be found, we looked for the closest Herfindahl index match among firms based on 1-digit SIC and no asset restrictions. ${ }^{7}$ We chose this matching system because we wanted to preserve the interpretation of our results as the difference between plan adopters and similarly diversified non-adopters. However, to control for possible endogeneity of plan adoptions, we perform our subsequent analysis of segment investment, allocation efficiency, and diversification discounts not only for the full sample, but also for the subsample of "expected adopters" vs. "unexpected non-adopters." The expectations are based on the Probit analysis of RI plan adoptions that utilized variables such as profitability, growth opportunities, or investment. Similar version of "propensity-based" matching has also been used by Hogan and Lewis, $2005 .^{8}$

Table 1 provides the description of our final sample of 89 companies that adopted RI plans from 1990 to 2001 (we did not find any diversified adopters with available data prior to 1990 or in 2002). Panel A shows the number of adoptions peaked at 15 in 1994, followed by a decline until 2001. Balachandran (2006) also documents a similar fall in RI plan adoptions. The adopter distribution by one-digit SIC codes presented in Panels B documents the majority of adopters are manufacturing firms ( $\mathrm{SIC}=3$ ). Panel C shows

\footnotetext{
${ }^{7}$ Out of 89 sample firms, we were able to identify matches based on 2-digit SIC code in 88 cases. The remaining one adopter obtained its match based on 1-digit SIC code without any asset size restriction.

${ }^{8}$ To further control for possible endogeneity of plan adoptions, in an unreported analysis we also performed 2-stage Heckman regressions for our full sample. The significances of the second-stage results (for segment investment, allocation efficiency, and diversification discounts) were nearly identical to those reported in the paper. In addition, the insignificance of Heckman correction coefficient " $\lambda$ " suggests low likelihood of a selection bias in our sample.
} 
that the most frequent adopters are in the following two digit SIC code industries: Industrial, Commercial Machinery and Computers (SIC=35) and in Electrical Equipment (SIC=36).

We also find (not reported in Table 1) that the plan adoptions, as well as any potential subsequent corporate policy changes, were unlikely to be performed due to perceived takeover threat, since none of the sample adopters were targeted for acquisition during the three years preceding the RI plan adoption.

\section{Results}

In this section, we present the results of our empirical analysis. First, we analyze the investment and divestiture changes surrounding RI plan adoption for diversified firms. Second, we study the segment performance (investment and profitability) of adopters. Third, we present the analysis of the investment efficiency of multi-segment firms that adopted RI plans - both on the segment level and in terms of company-wide Investment Efficiency. Fourth, we examine the impact of plan adoptions on diversification discount changes. Fifth, we compare the value gains achieved by diversified and focused adopters. Last, we analyze the determinants of plan eliminations.

\subsection{Investment and divestiture changes surrounding adoptions of RI plans by diversified firms}

Table 2 presents the univariate analysis of size, capital spending, and acquisition or divestiture changes for four years surrounding plan adoption. Expecting a fading impact of RI plans on performance in years more distant from adoption, we examine the significance of differences for $[-2$ years; +2 years $]$ and [-2 years; +3 years] event windows. Years -1 and +1 are skipped to avoid possible mismatches of calendar vs. fiscal years of plan adoptions and to correctly capture the changes from "before" to "after" the adoption. Both adopters and matching firms have very similar assets and sales (not surprisingly, as the matching was done based on assets). More importantly, RI plan adopters do not significantly change their firm-level capital expenditures, or acquisition and divestiture policies, both over time and when compared to the policies of matching firms. Consequently, the corporate performance improvements (in terms of returns on assets, diversification discounts, and Tobin's Q) documented in subsequent sections, are unlikely to be achieved due to "excessive" capital spending cuts or divestitures. Instead, any potential performance 
changes will be consistent with the improved allocation efficiency. Last, sample firms do not lower their level of diversification following the RI plan adoption. They have, on average, three segments and their median Herfindahl Index values stay close to 0.50 for all sample period years. The difference in diversification changes between the subsamples is significant at $10 \%$ level primarily due to slight diversification decrease for matching companies.

In the rest of the paper, we will focus on the analysis of gains due to RI plan adoption, as well as the possible sources of such gains. We will study how RI plans affect investment efficiency - both on the segment and firm levels - and how the potentially better investment decisions impact the firm's diversification discount.

\subsection{Diversified adopters' segment investment and profitability}

We show the primary segment-levels statistics in Table 3 . The results suggest that diversified RI plan adopters are associated with significant performance improvements. The median segment Return on Assets (Operating Earnings/Assets) significantly improves from $11.03 \%$ in year -2 to $13.25 \%$ in year +2 , and to $13.16 \%$ in year +3 . Segments of matching firms display no similar improvements, despite having no significantly different returns from adopting firms' segments prior to plan adoption. The analysis of Cash Flows (Operating Earnings + Depreciation) generated by segments demonstrates a similar trend. Median Cash Flows/Assets ratio rises from $16.29 \%$ in year -2 to $17.99 \%$ in year +2 and $18.56 \%$ in year +3 for adopting companies' segments. The segments of matching firms are not associated with similar improvements, despite having comparable pre-adoption performance. Previous research (e.g. Berger and Ofek, 1995) has identified overinvestment as one of the sources of value losses in diversified firms. The results in Table 3 indicate, however, that performance improvements of plan adopting segments cannot be fully explained by overinvestment reduction. Our results show that diversified firms adopting RI plans tend to reduce their investment. Segment Investment/Assets [industry-adjusted Investment/Assets] drops from $5.31 \%[0.90 \%]$ in year -2 to $5.07 \%[0.72 \%]$ in year +2 and to $4.78 \%[0.58 \%]$ in year $+3 .{ }^{9}$ The change over

\footnotetext{
${ }^{9}$ We define segment's industry in a particular year based on the most refined SIC code (4-, 3-, or 2-digit), which contains (in the same year) at least five single-segment firms with SIC codes equal to that of the segment.
} 
the window $[-2$ years; +3 years] is statistically significant at $5 \%$ level. However, Table 3 also shows that matching firms' segments experience similar investment reduction, albeit without performance gains.

RI plan adopters could achieve performance improvements without segment investment reductions if they divert capital expenditures toward segments with better-than-average growth opportunities (compared to the other firm's segments). The analysis of segment investment efficiency in Table 4 suggests that firms implementing RI plans indeed allocate capital relatively more efficiently. We measure segment growth opportunities by the median Tobin's Q (defined as [Market Value of Equity + Total Assets - Book Value of Equity] divided by Total Assets) of all single-segment firms in the same industry during a particular year. Our results in Panel A show that plan adopters significantly reduce their industry-adjusted investments in segments with growth opportunities below the firm's average growth opportunities from median of $1.18 \%$ in year -2 to $0.20 \%$ in year +3 . Panel B shows that over the same event window, adopters increase (albeit statistically insignificantly) their industry-adjusted investment in segments with aboveaverage growth opportunities from median of $0.24 \%$ in year -2 to $0.90 \%$ in year +3 . Interestingly, matching firms seem to follow the opposite investment pattern. The overall segment investment reduction by those firms documented in Table 3 appears to be primarily due to reduction of investment in segments with aboveaverage growth opportunities. Median industry-adjusted investment in such segments drops significantly from $1.49 \%$ in year -2 to $0.44 \%$ in year +2 and to $0.15 \%$ in year +3 . At the same time, the industry-adjusted investment in below-average growth opportunity segments by matching firms increases, although statistically insignificantly.

Overall, our results in Tables 3 and 4 support Hypothesis $H 1$ and are consistent with the previous research implying that RI plan adoptions may be value-creating. Segment ROA and Cash Flows/Assets improve significantly, while matching companies' segments do not show similar trends. Both adopters and their matching companies reduce segment level investment. However, while matching companies reduce primarily investment in segments with better (above firm-average) growth opportunities, firms implementing RI plans tend to cut capital spending of segments with poorer growth prospects. Such investment patterns are consistent with Hypothesis $H 2$ suggesting investment efficiency improvements for 
diversified adopters.

Nevertheless, conclusive inferences likely cannot be drawn from bivariate analysis in previous tables. First, the magnitude of differences could be questioned, since RI plan adoption is an endogenous event. Firms likely tend to adopt plans when they find them beneficial. The endogeneity of RI plan implementation will be discussed in the next subsection. Second, Shin and Stulz (1998) show that besides own growth opportunities, segment's investment is affected by segment's cash flows, as well as firm's cash flows and growth opportunities. To properly examine segment allocation efficiency of plan adopters, we will perform multivariate analysis in subsection 4.4.

\subsection{Determinants of RI plan adoptions}

Firms will likely adopt RI plans only when the managers find them more advantageous than any of the alternatives. Consequently, it is difficult to determine whether firms that performed well did so because they adopted such plans, especially if adoption and prior performance are linked. In order to test the impact of plan implementation, we should examine subsamples of firms that expectedly adopted the plans against those that were expected to, but did not adopt. In this subsection, we present Probit analysis of plan adoption determinants that will enable us to identify subsamples of "expected adopters" and "unexpected nonadopters." These subsamples will then be used in the subsections 4.4.-4.6. to provide robustness tests of investment allocation efficiency and value gains associated with plan implementation.

The Probit analysis of determinants of RI plan adoptions is presented in Table 5. Since we want to study how the level of industrial diversification affects adoption decisions, we append our sample of diversified adopters with 81 single-segment firms that implemented RI plans during the period 1987-2002 (these firms will be further analyzed in subsection 4.7.). ${ }^{10}$ The single-segment adopters were identified by the methodology described in Section III (i.e., the keyword search in proxy statements plus extra adopters from Hogan and Lewis (2005) sample). Factors expected to influence firm decisions to adopt RI plans

\footnotetext{
${ }^{10}$ The majority of our adopters ( 89 out of 170) are diversified firms, despite multi-segment firms being out-numbered approximately $2: 1$ by focused companies in the overall population of U.S. firms. This suggests that RI plans may indeed be an ideal performance measurement criterion for diversified corporations.
} 
include (anticipated sign in parentheses):

Firm size measured by Log of Total Assets (+): We expect larger firms to more likely adopt RI plans due to an easier absorption of transaction costs associated with such plans.

Profitability measured by Weighted Segment ROA (?): Managers of more profitable firms may be more willing to adopt compensation plans rewarding better performance. However, worse-performing companies may be in a greater need to adopt RI plans.

Diversification measured by Sales-based Herfindahl Index (?): Since this index is an inverse measure of diversification, a negative coefficient would support our Hypothesis $H 1$ that plan implementation benefits diversified firms. A negative coefficient would support alternative Hypothesis Hla.

Investment level measured by Industry-adjusted Investment/Assets (?): RI plans provide a charge for invested capital. Managers may try to avoid it, but shareholders may be in favor of such a plan.

Industry Growth Opportunities measured by the weighted average of industry $q$ 's of all company's segments (-): Garvey and Milbourn (2000) claim that computation of economic profits is difficult for fast growing firms, which lowers the likelihood of adoption of such plans.

Segment Diversity defined in Equation (2) (?): RI plan adopters with very diverse divisions likely face the greatest implementation challenges (division of shared costs and assets, acceptance of distinct profit targets by all divisions). At the same time, the adoptions also bring the highest benefits - the ability to assess true divisional value creation by considering different business risk.

Investment Efficiency defined in Equation (1) (?): Managers of firms that invest efficiently may be more willing to accept compensation plans rewarding efficiency. However, inefficient firms may benefit more by adopting RI plans.

Financial slack measured by Total Cash reserves/Total Assets (?): Firms with ample cash reserves may benefit the most from the investment discipline gained through plan adoption. Managers of such firms, however, may be less likely to adopt such plans, as it is difficult for cash to beat the cost of capital targets. Leverage measured by Total Debt/Total Assets (-): Leverage is considered a monitoring mechanism (e.g., Agrawal and Knoeber, 1996), so it can provide an alternative to RI plan adoption. 
Existing CEO bonus compensation measured by CEO Bonus Compensation/Total Compensation (-): Firms that already pay greater proportions of incentive compensation are likely subject to lower agency costs, lowering the likelihood of RI plan implementation.

CEO share ownership measured by CEO Shares Owned/Shares Outstanding (-): Firms with larger CEO stakes are likely subject to lower agency costs, lowering the likelihood of plan adoption.

Governance quality measured by G-Index developed by Gompers et al. (2003) (?): ${ }^{11}$ Companies with worse quality of governance may be in a greater need to adopt RI plans. However, managers of those companies may be entrenched, and thus unwilling to approve such plans.

Our empirical results in Table 5 suggest that the likelihood of RI plan adoption is increasing with the level of firm industrial diversification. Herfindahl Index is a significantly negative predictor of plan adoption in our basic Model 1, as well as when we control for the level of investment (Model 2), growth opportunities (Model 3), segment diversity and investment efficiency (Model 4), financial slack and leverage (Model 5), availability of alternative CEO bonus compensation and CEO ownership (Models 68), and the quality of governance (Model 9). In most of the models, the magnitude of Herfindahl Index coefficients ranges from -0.32 to -0.36 . These values imply that, when other control variables are held at their medians, there is between $71 \%$ and $86 \%$ greater chance of plan implementation by a firm with a Herfindahl Index of 0.50 (close to the sample median of our adopters) compared to the probability of adoption by a focused company.

Our results suggest that firms face significant costs associated with RI plan implementation. The significantly positive Firm size coefficient in Models 1-5 implies that typical adopters are large firms, consistent with the existence of fixed adoption costs. ${ }^{12}$ Similarly to Hogan and Lewis (2005), plans are primarily implemented by more profitable firms with lower investment levels and lower financial slack.

\footnotetext{
${ }^{11}$ Gompers et al. (2003) count the frequency of any of 24 firm charter or bylaws provisions restricting shareholder rights through antitakeover barriers or limitations of voting power, and aggregate the final score to form the G-Index. Consequently, firms with higher levels of G-Index are likely to be associated with worse governance.

${ }^{12}$ We further find that median asset size of all adopters, \$912 million, exceeds the size of non-adopting Compustat firms more than nine times. Incidentally, the negative sign for Size in Models 6-8 is not counter-intuitive, because our analysis there is restricted to large companies with compensation data available on Execucomp.
} 
Managers appear to accept these plans if they benefit due to high profits, but do not suffer due to high profit charges caused by high investment and/or cash levels. We do not find adoption decisions to be related to either Segment Diversity or company-wide Investment Efficiency. Any potential gains in allocation efficiency and/or value due to RI plan adoption are thus unlikely due to potential momentum reversals by previously underperforming adopters with high Segment Diversity. We further document that firms with higher levels of CEO ownership likely find adoption of plans based on economic profits less necessary, but we do not find a significant relation between plan adoption and the existing CEO bonus compensation. The positive coefficient on G-Index in Model 9 suggests that RI plans are more likely to be adopted by companies with lower quality of governance, and thus in need of better incentives.

In our subsequent analysis, we will use the results of Model 8 (with the best pseudo- $\mathrm{R}^{2}$ score) to establish the subsamples of "Expected Adopters" and "Unexpected Non-adopters" of RI plans. These subsamples will be used to test the impact of endogeneity of plan adoption decisions on investment and profitability of firms. ${ }^{13}$

\subsection{Multivariate analysis of segment investment by diversified RI plan adopters}

Table 6 presents the results of multivariate analysis of divisional investment by diversified firms that implemented RI plans. Our regression model design is similar to that of Shin and Stulz (1998) who show that cash flows are re-distributed in diversified firms, since the investment of a particular division depends on cash flows generated by the other divisions of the company. (Shin and Stulz (1998) claim the cash flow transfers do not create value, because the investment sensitivity to the cash flows is independent of segment growth opportunities.) Investment/Assets ratio of a particular segment is regressed on measures of own and other segments' growth opportunities, own and other segments' cash flows, and variables designed to examine the impact of plan adoption (Post-adoption*Adopter dummy variable, equal to one for years following adoption by RI plan adopting firms), and post-adoption time trend (Post-adoption dummy

\footnotetext{
${ }^{13}$ Model 8 successfully predicts $64 \%$ of all observations: $73 \%$ of sample adopters, and $42 \%$ of matching companies. The smaller incidence of correct identification of matching firms is not surprising. Since matching companies are diversified, they were expected to be adopters based on our Probit models.
} 
variable, equal to one for years following plan adoption for both the adopter and the matching firm). We also include firm- and calendar-year fixed effects to control for the panel-structure of our data (these coefficients are not reported in Table 6). In order to minimize the accounting mismatches between the year of plan adoption and the firm's fiscal year-end, we exclude years $-1,0$, and +1 from our Table 6 analysis (as well as from multivariate analyses in the following tables).

Model 1 shows that segment's investment of both adopters and their matching firms depends significantly on its own, and on other segments' cash flows. It appears capital expenditures of a particular company's division rise (fall), as the other divisions generate more (less) profits. This result implies redistribution of investment funds in a diversified firm (without redistribution, segment's investment should depend only on its own cash flows), and it is consistent with Shin and Stulz (1998) showing similar investment patterns for a large sample of all listed U.S. firms. Importantly, segment investment of firms in our sample is insensitive to segment's growth opportunities. This inability to secure extra investment funds by segments with superior growth opportunities is generally considered a sign of investment inefficiencies in diversified firms (Ozbas and Scharfstein, 2011).

In Model 2, we examine the impact of RI plan adoption on segment investment policies. We uncover three major results. First, and most importantly, segment investment of adopters becomes significantly related to segment's growth opportunities after the profit plans are implemented (the change in segment growth opportunities from $10^{\text {th }}$ to $90^{\text {th }}$ percentile of sample distribution leads to $1.4 \%$ increase in investment).. Second, the dependence of segment's investment on other segment's cash flows increases by roughly ten times during the post-adoption period for the adopters, suggesting that RI plans broaden, rather than diminish, functioning of internal capital markets. Third, we find that when controlling for other determinants, adopters actually significantly lower their post-adopting investment by $1.88 \%$ of segment assets. Overall, these results support our Hypothesis H2. RI plan implementation appears to be associated with investment reduction and increase in investment efficiency on the segment levels.

The specification of Model 3 is identical to that of Model 2. However, we restrict our analysis to subsamples of "Expected Adopters" and "Unexpected Non-adopters" identified by Probit analysis of RI 
plan choices. We expect the segment investment changes uncovered by the analysis of these subsamples to be primarily due to plan implementation. The results of Model 3 are nearly identical to those of Model 2 (though the coefficients for investment reduction and for sensitivity to segment's growth opportunities slightly increased in magnitude). Once again, our findings support Hypothesis $H 2$.

In Model 4, we utilize the sample and specification of Model 2, but add variables controlling for the impact of CEO turnover on the investment policies of our adopters. The consideration of 35 CEO replacements in the three-year window surrounding implementation of profit plans among the 89 diversified adopters helps us analyze the possibility that significant changes in segment investment policies attributed to plan adoption may be just the consequence of CEO replacement followed by a decision to adopt a RI plan. ${ }^{14}$ Our results show that all three adoption-related segment investment changes (greater sensitivity to segment's growth opportunities; greater impact of other segments' cash flows; investment reduction) remain unaffected by inclusion of CEO turnover variables. Also, except for marginally significant increase in the post-turnover impact of other segments' cash flows, none of CEO turnover variables affect segment investment policies. ${ }^{15}$ Consequently, the segment efficiency improvements documented in Models 2 and 3 are likely the direct consequences of plan adoptions.

\subsection{Investment Efficiency changes following RI plan adoptions}

Rajan et al. (2000) introduce the measure of company-wide Investment Efficiency, defined in Equation (1). They show that (a) Investment Efficiency of diversified firms worsens as Segment Diversity, defined in Equation (2), increases and (b) diversification discount decreases for firms with greater Investment Efficiency. Our results in the previous subsection suggest firms pursue more efficient segment investments following the adoption of RI plans. This subsection will study changes in company's overall

\footnotetext{
${ }^{14}$ The 39\% CEO turnover within the three year period does not appear to be excessive given the average CEO tenure of less than 7 years between 1992 and 2005 (Kaplan and Minton, 2006).

${ }^{15}$ In unreported analysis, we also find that CEO turnover variables remain insignificant in the model specification where we omit the plan-related variables. We find the same insignificant impact of CEO turnover in models with omitted plan-related variables in the later analysis of Investment Efficiency (Table 7) and of diversification discount (Table VIII) determinants. While Lehn and Makhija (1997) show that company's RI plan levels are superior predictors of managerial turnover, our findings are consistent with $\mathrm{Li} \mathrm{(2004)}$ and suggest that managerial turnover per se is not sufficient for performance improvements in diversified firms.
} 
Investment Efficiency surrounding plan implementation. Valuation impact of Investment Efficiency changes will be examined in the next subsection.

Table 7 presents the analysis of Investment Efficiency. To obtain coefficients with larger absolute values, we multiply Investment Efficiency defined in Equation (2) by a factor of 100. The explanatory variables - Segment Diversity, the inverse of segment $q$ 's average, firm size, and firm and calendar-year fixed effects (unreported in Table 7) - are analogous to those used by Rajan et al. (2000). We also include Post-adoption and Adopter dummy variables, as well as interactive coefficients of those dummy variables with Segment Diversity. The results of Model 1 suggest that RI plan implementation is associated with significant improvements in post-adoption Investment Efficiency. The size of the change (0.2457) exceeds the inter-quartile range of Investment Efficiency distribution, and its economic implication will be examined in the next subsection. Similarly to Rajan et al. (2000), we find Segment Diversity negatively affects Investment Efficiency. Our results also show post-adoption time trend (measured by Post-adoption dummy) is not associated with significant Investment Efficiency changes. Model 2 examines the impact of plan adoption on the strength of the negative relationship between Segment Diversity and Investment Efficiency. If implementation of RI plans improves internal capital markets, then the diversity in segment growth opportunities should have a less negative impact on Investment Efficiency. We find that Segment Diversity is associated with a significantly negative coefficient (-1.44) and that the marginal effect of Segment Diversity in post-adoption years is also negative (-1.51). However, the marginal post-adoption effect of Segment Diversity for adopters is significantly positive $(+2.27)$. The post-adoption impact of Segment Diversity is still negative for firms implementing RI plans $(-0.68=-1.44-1.51+2.27)$, but indeed significantly less so than that for matching firms $(-2.95=-1.44-1.51)$. Model 3 shows that the post-adoption marginal impact of Segment Diversity on Investment Efficiency stays significantly positive for adopters even when we do not consider the impact of post-adoption trend on the relation between Segment Diversity and Investment Efficiency.

Models 4-6 utilize the same specification as Models 1-3, but the sample analyzed includes only "Expected Adopters" and "Unexpected Non-adopters" of RI plans. The statistical significance of all 
coefficients reflecting positive impact of plan adoption on Investment Efficiency remains unchanged when we analyze those two subsamples where the differences - as we argued above - arise more likely primarily due to plan adoption. The magnitudes of the plan-related coefficients actually slightly increase. In Models 7-9, we use the sample and specifications of Models 1-3, but we add variables related to the CEO turnover in adopters. We find that CEO turnover does not significantly affect our results suggesting beneficial impact of plan adoption on functioning of internal capital markets and on Investment Efficiency. In addition, none of the CEO turnover-related variables seems to be a significant predictor of Investment Efficiency levels. In Model 10, we test the impact of plan adoption on Investment Efficiency separately for diversified firms with related (9 sample adopters with all segments sharing the same 3-digit SIC codes,) and unrelated segments (remaining 80 sample adopters). We expect RI plan implementation to be less beneficial for the firms with divisions operating in the same industry, as one of the perceived plan advantages is creation of unique, industry risk-specific profit targets. Even though the marginal impact of plan adoption for firms with related segments is negative, as anticipated, the coefficient is statistically insignificant. Overall, the results in Table 7 support Hypothesis $H 3$ predicting Investment Efficiency improvements after the adoption.

\subsection{Diversification discount changes following RI plan adoptions}

Previous studies (e.g., Hoechle et al., 2012; Rajan et al., 2000; Berger and Ofek, 1995) have documented that diversified firms sell with negative excess values - that is, at a "diversification discount" - with respect to the value of divisional assets as self-standing units. Rajan et al. (2000) further show that excess value is a negative (positive) function of Segment Diversity (Investment Efficiency). So far, we showed that RI plan adoption is associated with Investment Efficiency improvements, as well as with lower efficiency-reducing effect of Segment Diversity. In this section, we will examine whether these two consequences of plan implementation have an impact on the value of adopters - that is, whether the postadoption diversification discount decreases for firms implementing RI plans.

The results of the diversification discount analysis are presented in Table 8. Following Berger and Ofek (1995), we define Excess Value (i.e., "diversification discount/premium” if negative/positive) as In[Market Value of Assets/Imputed Value]. Market Value of Assets is computed as Market Value of Equity 
+ Total Assets - Book Value of Equity. The Imputed Value of a firm is calculated as a sum of segments' imputed values. To compute imputed value of a segment, we multiply its Assets by the Assets Multiple (equal to median 'Market Value of Assets'-to-Assets ratio of all single-divisional firms in the segment's industry). ${ }^{16}$ Table 8 contains results of our analysis of the determinants of diversification discount. To control for the endogeneity of diversification decisions (e.g., Campa and Kedia, 2002), we also include firm and calendar-year fixed effects (coefficients not reported in Table 8).

Consistent with previous research, we find less diversified companies are associated with a smaller diversification discount, since Herfindahl Index is a positive determinant of Excess Value in all Table 8 models. More importantly, Model 1 shows that compared to their matching firms, RI plans adopters trade at a diversification premium of $6.8 \%$ following plan implementation. ${ }^{17}$ In Model 2, the significantly positive coefficient for Investment Efficiency is consistent with the findings of Rajan et al. (2000). Model 1 in Table 7 shows that adopters improve their Investment Efficiency on average by 0.25 . This Investment Efficiency improvement implies firms implementing RI plans trade at a post-adoption premium of $0.1866^{*} 0.25=$ 4.7\%. The premium is attributable to improved investment efficiency of adopters. In Model 3, we show RI plan adopter diversification premium remains significant even after controlling for the negative impact of Segment Diversity documented by Rajan et al. (2000). Model 4 results show Segment Diversity has a less adverse impact on post-adoption Excess Value of adopters. Since mean Segment Diversity for RI plan adopters in our sample is 0.097 (with very little variation from before to after the adoption). Model 4 implies (based on the coefficient value for Segment Diversity* Post-adoption* Adopter) a diversification premium of the magnitude of $0.65^{*} 0.097=6.3 \%$. This premium can be attributed to a diminished negative effect of Segment Diversity following plan implementation, consistent with improvements in efficiency of internal

\footnotetext{
${ }^{16}$ In unreported analysis, we alternatively measured diversification discounts utilizing imputed values based on segment Sales. That is, to compute imputed value of a segment, we multiply its Sales by the Sales Multiple (equal to median 'Market Value of Assets'-to-Sales ratio of all single-divisional firms in the segment's industry). In terms of statistical significance, the results were virtually identical to those presented in Table 8 .

${ }^{17}$ More precisely, since Excess Value of adopters is measured compared to similarly diversified matching firms, any observed diversification premiums can be considered diversification discount reductions with respect to the typical discount associated with matching firm values.
} 
capital markets.

Models 5-8 utilize the same specification as Models 1-4, but we analyze the subsamples where significance of results is more likely due to plan adoption - "Expected Adopters" vs. "Unexpected Nonadopters". Our results show that the statistical significance of all plan-related variables remains unchanged. The magnitudes of estimated diversification premiums actually increase from $6.8 \%$ to $11.1 \%$. Model 9 employs the same sample and specification as Model 1, but we add a dummy variable measuring the postadoption impact of CEO turnover on diversification discount. Similarly to results presented in previous tables, we find that CEO changes do not significantly affect Excess Value of plan adopters. These findings are consistent with Li (2004) who finds replacement of a CEO is not significantly related to investment efficiency improvements or value gains in diversified firms. Model 10 tests the benefits of plan implementation separately for adopters with related vs. unrelated divisions. Similarly to Table 7, we find weak evidence that adoption benefits more firms with segments that operate in distinctly different industries. Overall, the results in Table 8 support our Hypothesis $H 4$ expecting post-adoption diversification discount reduction for firms implementing RI plans.

\subsection{Performance changes following RI plan adoptions by diversified vs. focused firms}

So far, we have documented internal capital market improvements, and corresponding performance gains following plan adoptions by diversified firms. As a robustness check, we now provide the comparison of performance changes following plan implementation based on whether the adopter is a diversified, or a focused company. Unlike multi-divisional entities, single-segment firms generally do not have to consider the impact of different riskiness associated with projects adopted by different divisions and/or the relative limited contribution of a single divisional manager toward firm value (Keating, 1997). RI plans should thus be just one of several alternative criteria (alongside variables based on stock price and company-wide accounting profitability) available for single segment firms to assess managerial and firm performance. Consequently, we expect the impact of plan adoption on the performance of focused firms to be less significant when compared to the performance of matching firms.

Table 9 provides evidence on the overall valuation impact of plan adoption conditional on adopter 
diversification status. We analyze determinants of company's Tobin's Q for adopters and their matching companies. Single-segment adopters are assigned matching firms using the algorithm described in Section III. (We preserve the diversification status, and the matching companies are consequently focused.) Our variables measuring the impact of plan adoption include Post-adoption dummy variable and Postadoption*Adopter dummy variable. Besides size (equal to the log of Sales), we also control for profitability (measured by weighted average of segments' Return on Assets, ROA) and firm's growth opportunities (equal to the weighted average of median industry Tobin's Q's of company's segments). We expect both of those variables to have a positive impact on firm's Tobin's Q. In addition, we control for the level of firm's diversification measured by the sales-based Herfindahl Index. We expect Herfindahl Index (an inverse measure of diversification) to be positively related to Tobin's Q, in accordance with research suggesting diversification has a negative impact on value. Our control variables also include firm- and calendar-year fixed effects to control for the panel-structure of our data (coefficients not reported in Table 9).

Models 1 and 2 in Table 9 analyze the impact of RI plans adoptions for diversified firms. Similarly to Table 8, our results suggest that multi-divisional firms adopting RI plans increase in value. During postadoption years, Tobin's Q of such firms increases (statistically significantly) by 0.11 . As expected, industry growth opportunities and profitability have a positive effect on Tobin's Q. The positive coefficient for the Herfindahl Index suggests that the level of diversification affects Tobin's Q negatively. The insignificant coefficient for Post-adoption dummy is consistent with no persistent inter-temporal trend in Tobin's Q levels for both adopters and matching firms.

In contrast, no significant effect of plan implementation is detected for single-segment firms based on the results of Models 3-4 in Table 9. The Post-adoption*Adopter dummy is in fact very close to zero in both models. ${ }^{18}$ Overall, Table 9 results imply that the value gains are restricted to multi-divisional adopters. This finding suggests that RI plans can be particularly useful for diversified adopters, while focused firms

\footnotetext{
${ }^{18}$ In unreported analysis, we find that the ROE and M/B of equity also do not significantly change for focused adopters around the time of the plan adoption - both over time and when compared to matching companies.
} 
may have a greater range of alternative mechanisms motivating managers (based on company-wide accounting and stock performance variables).

\subsection{Determinants of RI plan eliminations}

If RI plans are costly, it may be expected that companies will not use those plans permanently. In fact, from the adoption year until 2009, 40 out of 89 (45\%) of our sample multi-segment adopters had eliminated the plans. In this section, we examine the factors leading previous adopters to eliminate the plans. Principally, there can be three reasons for these actions. First, our analysis in section 4.3. suggests that plan approvals are likely "manager-driven". Companies adopt RI plans if they have the potential to immediately benefit the managers (the adopters are primarily profitable firms with lower investment levels and lower financial slack). If the plan eliminations are similarly "manager-motivated," we expect that firms would decide to drop the plans if their profitability is low, investment levels and/or cash reserves are high, and if the managers are paid low bonuses. Second, if, on the other hand, RI plans are efficiently eliminated after improvement in the functioning of internal capital markets and are no longer necessary, then the plans should be dropped if the firm profitability is high. Third, eliminations can be considered actions that correct previously suboptimal adoptions, especially in cases when the companies are not substantially diversified and do not have significant investment activities (and thus RI plans were not needed to help with the functioning of the internal capital markets).

For the examination of eliminations, we restrict the sample to the 89 diversified adopters. The dependent variable is equal to 1 if the adopter no longer uses the plan during the particular year (starting from the year after adoption until 2009). The set of explanatory variables is similar to that we used in section 4.3. (in Table 5) to explain plan adoptions. That is, we consider the firm-specific variables such as size (Log of Total Assets), profitability (Return on Assets), diversification (Herfindahl Index), capital expenditures (Capex/Assets), cash reserves (Total Cash/Assets), and leverage (Total Debt/Assets). In addition, we control for the CEO share ownership, CEO bonuses (Bonus/Total Compensation), and the quality of firm governance (G-Index). The significance of our results was nearly identical when the decision not to use the RI plan was determined by the independent variables lagged by one year. 
The Probit analysis of RI plan eliminations is presented in Table 10. Our results show that the plans tend to be eliminated by large, less profitable companies, as well as by firms where managers do not earn high bonuses (the coefficients for both ROA and Bonus/Total Compensation are significantly negative). In addition, eliminations are positively - albeit insignificantly - related to higher cash reserves. Consequently, these findings suggest that eliminations can be indeed management-driven - firms drop these plans when they likely generate negative residual income, and thus may penalize managers. We also find that firms drop plans when they are less diversified and when they invest less (the coefficient for Herfindahl Index is significantly positive, while the coefficient for Capex/Assets is significantly negative). Since low diversification and low investment are indicators of less relevant internal capital markets, it appears that firms may drop RI plans when they have lower potential to help functioning of internal capital markets. Regarding other determinants, eliminations appear to be unaffected by managerial turnover, CEO share ownership, or growth opportunities, but are more likely for less-levered adopters. Overall, Table 10 results imply that the decisions not to continue utilizing RI plans may correct some previously suboptimal adoptions. In addition, we also show that despite their advantages, plans tend to be dropped once they no longer generate positive residual income, and thus likely lead to lower managerial bonuses.

In unreported analysis, we also studied the effect of RI plan eliminations on functioning of internal capital markets. That is, we replicated the analysis of Investment Efficiency (Table 7) and of Diversification Discount (Table 8) during the four years surrounding plan eliminations. Our results showed that postelimination, the investment efficiency of past adopters slightly worsened, and the diversification discount slightly increased - both consistent with an adverse effect of plan eliminations on functioning of internal capital markets. However, none of those effects were significant.

\section{Conclusion}

Recent research has identified deficiencies associated with the functioning of internal capital markets in diversified firms. Multi-divisional companies have been shown to allocate capital inefficiently across divisions. Less efficient segments tend to receive extra investment funds at the expense of divisions 
with superior growth opportunities. Ultimately, diversified firms tend to sell at "diversification discounts," reflecting value losses due to problems in internal capital markets. In this paper, we examine how the functioning of internal capital markets is affected by the use of Residual Income (RI) plans.

Our study presents four major results. First, RI plans are associated with significant value gains in diversified - but not in single-segment - firms. Second, diversified firms follow more efficient segmentlevel investment policies after the adoption of the plans. Segment-level investment becomes positively dependent on the growth opportunities, while the overall investment levels decline. Third, company-wide Investment Efficiency significantly improves and becomes less negatively dependent on overall dispersion of segments' growth opportunities for multi-divisional firms that implement the plans. Fourth, the diversification discount becomes significantly smaller after the adoption of RI plans. All our findings are robust to considerations of endogeneity of adoption decisions, and to the impact of CEO turnovers or the threat of takeovers.

We also document that firms implementing the plans likely face significant costs, leading to the relatively low adoption rate among U.S. firms. We find that adopters tend to be primarily large diversified firms with managers likely to immediately benefit from the plans due to larger pre-adoption profits, lower investment and small financial slack. Similarly, RI plans tend to be eliminated if the company profitability declines and managers receive lower bonuses. Consequently, despite the advantages, plan adoptions/eliminations appear to be often motivated by managerial benefits.

Yet, overall, our results suggest that adoptions of RI plans mitigate problems of internal capital markets. Those plans are associated with net benefits for diversified firms, consistent with their ability to penalize excessive use of capital. 


\section{References}

Agrawal, A. and C. Knoeber, 1996, Firm performance and mechanism to control agency problems between managers and shareholders, Journal of Financial and Quantitative Analysis 31, 377-397.

Ahn, S. and D.J. Denis, 2004, Internal capital markets and investment policy: evidence from corporate spinoffs, Journal of Financial Economics 71, 489-516.

Ahn, S., D.J Denis and D.K Denis, 2006, Leverage and investment in diversified. firms, Journal of Financial Economics 79, 317-337.

Arya, A. and B. Mittendorf, Supply Chains and Segment Profitability: How Input Pricing Creates a Latent Cross-Segment Subsidy, Accounting Review 86, 805-824.

Bacidore, J., J. Boquist, T. Milbourn and A. Thakor, 1997, The search for the best financial performance measure, Financial Analysts Journal 53, 11-20.

Balachandran, S.V., 2006, How does residual income affect investment? The role of prior performance measures, Management Science 52, 383-394.

Baldenius, T., S. Dutta and S. Reichelstein, 2007, Cost Allocation for Capital Budgeting Decisions, Accounting Review 82, 837-867.

Barniv, R., O.-K. Hope, M.J. Myring and W.B. Thomas, 2009, Do Analysts Practice What They Preach and Should Investors Listen? Effects of Recent Regulations, Accounting Review 84, 1015-1039.

Beneish, M.D, I.P. Jansen, M.F. Lewis and N.V. Stuart, 2008, Diversification to mitigate expropriation in the tobacco industry, Journal of Financial Economics 89, 136-157.

Bens, D., Berger, P.G., and S.J. Monahan, 2011, Discretionary Disclosure in Financial Reporting:An Examination Comparing Internal Firm Data to Externally Reported Segment Data, Accounting Review 86, 417-449.

Berger, P.G., and E. Ofek, 1995, Diversification's Effect on Firm Value, Journal of Financial Economics 37, 39-65.

Bernardo, A.E., J. Luo, Wang, J.J.D., 2006, A theory of socialistic internal capital markets, Journal of Financial Economics 80, 485-509.

Berry, T., J.M. Bizjak, M.L. Lemmon and L. Naveen, 2006, Organizational complexity and CEO labor markets: Evidence from diversified firms, Journal of Corporate Finance 12, 797-817.

Biddle, G.C., R.M. Bowen, and J.S. Wallace, 1997, Does Eva ${ }^{\circledR}$ beat earnings? Evidence on associations with stock returns and firm values." Journal of Accounting and Economics 24, 301-336.

Borghesi, R., J. Houston and A. Naranjo, 2007, Value, Survival, and the Evolution of Firm Organizational Structure, Financial Management 36, 5-31.

Bouwens, J. and L. van Lent, 2007, Assessing the Performance of Business Unit Managers, Journal of Accounting Research 45, 667-697. 
Burch, T.R. and V. Nanda, 2003, Divisional diversity and the conglomerate discount: evidence from spinoffs, Journal of Financial Economics 70, 69-98.

Campa, J.M. and S. Kedia, 2002, Explaining the Diversification Discount, Journal of Finance 57, 17311762.

Chen, P.F. and G. Zhang, 2007, Segment Profitability, Misvaluation, and Corporate Divestment, Accounting Review 82, 1-26.

Chen, P.F. and G. Zhang, 2003, Heterogeneous Investment Opportunities in Multiple-Segment Firms and the Incremental Value Relevance of Segment Accounting Data, Accounting Review 78, 397-428.

Chen, S., 2006, The Economic Impact of Corporate Capital Expenditures: Focused Firms versus Diversified Firms, Journal of Financial and Quantitative Analysis 41, 341-355.

Comment, R. and G.A. Jarrell, 1995, Corporate focus and stock returns, Journal of Financial Economics 37, 67-87.

Core, J.E., R.W. Holthausen and D.F. Larcker, 1999, Corporate governance, chief executive officer compensation and firm performance, Journal of Financial Economics 51, 371-406.

Cremers, K.J.M., R. Huang and Z. Sautner, 2011, Internal Capital Markets and Corporate Politics in a Banking Group, Review of Financial Studies 24, 358-401.

Daley, L., V. Mehrotra and R. Sivakumar, 1997, Corporate focus and value creation: evidence from spinoffs, Journal of Financial Economics 45, 257-281.

Datta, S., R. D'Mello and M. Iskandar-Datta, 2009, Executive compensation and internal capital market efficiency, Journal of Financial Intermediation 18, 242-258.

Dechow, P., A.P.Hutton and R.G. Sloan, 1999, An empirical assessment of the residual income valuation model, Journal of Accounting and Economics 26, 1-34.

Desai, A.S., A.M. Fatemi and J.P. Katz, 2003, Wealth creation and managerial pay: MVA and EVA as determinants of executive compensation, Global Finance Journal 14, 159-179.

Dittmar, A. and A. Shivdasani, 2003, Divestitures and divisional investment policies, Journal of Finance $58,2711-2743$.

Dos Santos, M.B., V.R. Errunza and D.P. Miller, 2008, Does corporate international diversification destroy value? Evidence from cross-border mergers and acquisitions, Journal of Banking and Finance 32, 27162724.

Dutta, S. and Q. Fan, 2009, Hurdle Rates and Project Development Efforts, Accounting Review 84, 405432.

Ehrbar, A. and G.B. Stewart III, 1999, The EVA revolution, Journal of Applied Corporate Finance 12, 1831.

Fernandez, P., 2001, EVA, Economic Profit and Cash value added do NOT measure shareholder value creation." Working Paper, IESE Business School. 
Fauver, L., J. Houston and A. Naranjo, 2003, Capital market development, international integration, legal systems, and the value of corporate diversification: a cross-country analysis, Journal of Financial and Quantitative Analysis 38, 135-157.

Fluck, Z. and A. Lynch, 1999, Why firms merge and then divest: A theory of financial synergy, The Journal of Business 72, 319-346.

Garvey, G.T. and T.T. Milbourn, 2000, EVA versus earnings: Does it matter which is more highly correlated with stock returns?, Journal of Accounting Research 38, 209-245.

Gertner, R. H., E. Powers and D. S. Scharfstein, 2002, Learning about internal capital markets from corporate spin-offs, Journal of Finance 57, 2479-2506.

Gertner, R. H., D. S. Scharfstein, and J. C. Stein, 1994, Internal versus External Capital Markets, The quarterly Journal of Economics 109, 1211-1230.

Gompers, P., J. Ishii, and A. Metrick, 2003, Corporate Governance and equity prices, Quarterly Journal of Economics 118, 107-155.

Gopalan, R. and K. Xie, 2011, Conglomerates and Industry Distress, Review of Financial Studies 24, 36423687.

Graham, J.R., M.L. Lemmon and J.G. Wolf, Does corporate diversification destroy value?, Journal of Finance 57, 695-720.

Hoechle, D., M. Schmid, I. Walter and D. Yermack, 2012, How much of the diversification discount can be explained by poor corporate governance?, Journal of Financial Economics 103, 41-60.

Hogan, C.E. and C.M. Lewis, 2005, Long-run investment decisions, operating performance and shareholder value creation of firms adopting compensation plans based on Economic Profits, Journal of Financial and Quantitative Analysis 40, 721-745.

Jensen, M.C. and W.H. Meckling, 1992, Specific and general knowledge and organizational structure, in W. Lars and H. Wijkander (eds.), Contract Economics. Oxford, Basil Blackwell: 251-274.

Jensen, M.C., and K.J. Murphy, 1990, Performance pay and top management incentives, Journal of Political Economy 98, 225-264.

John, K. and E. Ofek, 1995, Asset sales and increase in focus, Journal of Financial Economics 37, 105-126.

Kaplan, S. and B. Minton, 2006, How has CEO turnover changed? Increasingly performance sensitive boards and increasingly uneasy CEOs, Working Paper, The Ohio State University.

Keating, A.S., 1997, Determinants of divisional evaluation practices, Journal of Accounting and Economics 24, 243-273.

Laeven, L. and R. Levine, 2007, Is there a diversification discount in financial conglomerates?, Journal of Financial Economics 85, 331-367. 
Lehn, K. and A. K. Makhija, 1997, EVA, Accounting Profits, and CEO Turnover: An Empirical Examination, 1985-1994, Journal of Applied Corporate Finance 10, 90-97.

Lewellen, W.G., 1971, A pure financial rationale for the conglomerate merger, Journal of Finance 26, 521537.

Li, Q., 2004, CEO turnover and divisional investment, Working paper, Georgia State University.

Lin, J.B., C. Pantzalis and J.C.Park, 2007, Corporate use of derivatives and excess value of diversification, Journal of Banking and Finance 31, 889-913.

Lins, K. and Servaes H., 1999, International evidence on the value of corporate diversification, Journal of Finance 54, 2215-2239.

Majd, S. and S.C. Myers, 1987, Tax asymmetries and corporate income tax reform, in: M. Feldstein, ed., Effects of taxation on capital accumulation (University of Chicago Press, Chicago, IL).

Mehran, H., 1995, Executive compensation structure, ownership, and firm performance, Journal of Financial Economics 38, 163-184.

Milano, G.V., 2000, EVA and the 'New Economy', Journal of Applied Corporate Finance 13, 118-128.

O'Byrne, S.F., 1996, EVA and market value, Journal of Applied Corporate Finance 9, 116-125.

O'Byrne, S.F. and S.D. Young, 2009, Why Capital Efficiency Measures Are Rarely Used in Incentive Plans, and How to Change That, Journal of Applied Corporate Finance 21, 87-92.

Ozbas, O. and D.S. Scharfstein, 2010, Evidence on the Dark Side of Internal Capital Markets, Review of Financial Studies 23, 581-599.

Rajan, R., H. Servaes, and L. Zingales, 2000, The cost of diversity: The diversification discount and inefficient investment, Journal of Finance 60, 35-80.

Riceman, S.S., S.F. Cahan and M. Lal, 2002, Do managers perform better under EVA bonus schemes?, European Accounting Review 11, 537-572.

Scharfstein, D. S. and J. Stein, 2000, The dark side of internal capital markets: Divisional rent-seeking and inefficient investment, Journal of Finance 55, 2537-2564.

Schmid, M.M. and I. Walter, 2009, Do financial conglomerates create or destroy value?, Journal of Financial Intermediation 18, 193-216.

Schoar, A., 2002, Effects of corporate diversification on productivity, Journal of Finance 57, 2379-2403.

Servaes, H., 1996, The value of diversification during the conglomerate merger wave, Journal of Finance $51,1201-1225$.

Shin, H. and R. Stulz, 1998, Are Internal Capital Markets Efficient? Quarterly Journal of Economics 113, 531-552. 
Stein, J.C., 1997, Internal capital markets and the competition for corporate resources, Journal of Finance $52,111-134$.

Stulz, R.M., 1990, Managerial discretion and optimal financing policies, Journal of Financial Economics 26, 3-27.

Villalonga, B., 2004, Diversification discount or premium? New evidence from the business information tracking series. Journal of Finance 59, 479-506.

Wallace, J.S., 1997, Adopting residual income-based compensation plans: Do you get what you pay for?, Journal of Accounting and Economics 24, 275-300.

Weaver, S.C., 2001, Measuring Economic Value Added: A survey of the practices of EVA proponents, Journal of Applied Finance 11, 50-60.

Weston, J.F., 1970, The nature and significance of conglomerate firms, St. John's Law Review 44, 66-80.

Xuan, Y., 2009, Empire building or bridge building? Evidence from new CEO's internal capital allocation decisions, Review of Financial Studies 22, 1419-1448.

Yan, A., Yang, Z. and Jiao, J.: 2010, Conglomerate investment under various capital market conditions, Journal of Banking \& Finance 34, 103-115. 
Table 1

Sample Description

Panel A: RI Plan Adoptions by Years

\begin{tabular}{ll|l}
$\begin{array}{l}\text { Adoption } \\
\text { Year }\end{array}$ & Diversified adopters \\
\hline 1990 & \\
1991 & 2 \\
1992 & 2 \\
1993 & 3 \\
1994 & 6 \\
1995 & 15 \\
1996 & 12 \\
1997 & 10 \\
1998 & 9 \\
1999 & 10 \\
2000 & 8 \\
2001 & 6 \\
& 6 \\
Total & 89
\end{tabular}

Panel B: RI Plan Adoptions by SIC codes

\begin{tabular}{l|c}
$\begin{array}{l}\text { SIC } \\
\text { Range }\end{array}$ & Diversified adopters \\
\hline $0100-0999$ & \\
$1000-1999$ & 1 \\
$2000-2999$ & 3 \\
$3000-3999$ & 21 \\
$4000-4999$ & 42 \\
$5000-5999$ & 5 \\
$6000-6999$ & 8 \\
$7000-7999$ & 2 \\
$8000-8999$ & 5 \\
$9000-9999$ & 2 \\
& 0 \\
Total & 89
\end{tabular}


Panel C: Most Frequent SIC Codes of RI Plan Adopters

\begin{tabular}{l|l}
$\begin{array}{l}\text { Most Frequent 2-digit } \\
\text { SIC Codes }\end{array}$ & Diversified adopters \\
\hline & $\begin{array}{l}35(10 \text { times }): \text { Industrial, Commercial Machinery and Computers } \\
36(10 \text { times }): \text { Electrical Equipment } \\
28(8 \text { times }): \text { Chemical and Allied Products } \\
20(5 \text { times }): \text { Food and Kindred Products } \\
38(5 \text { times }): \text { Photo Goods and Watches }\end{array}$
\end{tabular}


Table 2

Firm Characteristics Around RI Plan Adoptions by Diversified Firms

Median levels presented. Assets, Sales in constant 2002 dollars. Reldif provides the relative difference in years with respect to RI plan adoption. Capx/A, Disp/A and Acq/A denote Capital Expenditures, Dispositions and Acquisitions normalized by Total Assets. Herfind. denotes sales-based Herfindahl Index (the sum of squared divisional sales weights). Nseg represents the number of company's industrial segments. The numbers in parentheses indicate the mean number of segments.

Adopters:

\begin{tabular}{rrrllllrr} 
reldif & N & Assets & Sales & Capx/A & Disp/A & Acq/A & Herfind. & Nseg \\
-4 & 85 & 1470 & 1976 & 0.0689 & 0.0018 & 0.0000 & 0.5251 & $3(2.6)$ \\
-3 & 85 & 1494 & 2032 & 0.0556 & 0.0014 & 0.0000 & 0.5139 & $3(2.6)$ \\
$-\mathbf{2}$ & $\mathbf{8 8}$ & $\mathbf{1 5 2 9}$ & $\mathbf{2 0 8 3}$ & $\mathbf{0 . 0 5 3 1}$ & $\mathbf{0 . 0 0 2 2}$ & $\mathbf{0 . 0 0 0 4}$ & $\mathbf{0 . 5 0 9 8}$ & $\mathbf{2 . 5}(\mathbf{2 . 6})$ \\
-1 & 88 & 1741 & 2054 & 0.0502 & 0.0020 & 0.0012 & 0.5061 & $3(2.7)$ \\
0 & 89 & 1861 & 2091 & 0.0526 & 0.0027 & 0.0000 & 0.5011 & $3(2.9)$ \\
1 & 88 & 1895 & 2133 & 0.0570 & 0.0024 & 0.0004 & 0.5046 & $3(2.8)$ \\
$\mathbf{2}$ & $\mathbf{8 4}$ & $\mathbf{1 8 9 9}$ & $\mathbf{2 3 0 3}$ & $\mathbf{0 . 0 5 2 1}$ & $\mathbf{0 . 0 0 2 3}$ & $\mathbf{0 . 0 0 4 7}$ & $\mathbf{0 . 5 0 2 3}$ & $\mathbf{3}(\mathbf{2 . 9})$ \\
$\mathbf{3}$ & $\mathbf{7 4}$ & $\mathbf{1 9 1 7}$ & $\mathbf{2 0 9 1}$ & $\mathbf{0 . 0 4 7 5}$ & $\mathbf{0 . 0 0 1 1}$ & $\mathbf{0 . 0 0 2 3}$ & $\mathbf{0 . 5 0 0 6}$ & $\left.\mathbf{3}^{*}(\mathbf{2 . 9})^{*}\right)$ \\
4 & 69 & 1830 & 2218 & 0.0457 & 0.0035 & 0.0061 & 0.4755 & $3(3.1)$ \\
Matching & Firms & & & & & & & \\
reldif & $\mathrm{N}$ & Assets & Sales & Capx/A & Disp/A & Acq/A & Herfind. & Nseg \\
-4 & 79 & 1202 & 1541 & 0.0572 & 0.0006 & 0.0006 & 0.5521 & $3(2.9)$ \\
-3 & 81 & 1242 & 1654 & 0.0534 & 0.0005 & 0.0003 & 0.5827 & $2(2.6)$ \\
$-\mathbf{2}$ & $\mathbf{8 5}$ & $\mathbf{1 3 9 9}$ & $\mathbf{1 5 8 5}$ & $\mathbf{0 . 0 5 6 0}$ & $\mathbf{0 . 0 0 0 7}$ & $\mathbf{0 . 0 0 0 9}$ & $\mathbf{0 . 5 0 1 4}$ & $\mathbf{3}(\mathbf{2 . 8})$ \\
-1 & 86 & 1442 & 1691 & 0.0521 & 0.0016 & 0.0000 & 0.5541 & $3(2.8)$ \\
0 & 89 & 1571 & 1771 & 0.0512 & 0.0010 & 0.0040 & 0.5077 & $3(3.0)$ \\
1 & 85 & 1756 & 1841 & 0.0543 & 0.0011 & 0.0001 & 0.5493 & $3(2.9)$ \\
$\mathbf{2}$ & $\mathbf{8 0}$ & $\mathbf{1 7 4 2}$ & $\mathbf{1 8 3 8}$ & $\mathbf{0 . 0 4 3 3}$ & $\mathbf{0 . 0 0 1 0}$ & $\mathbf{0 . 0 0 3 6}$ & $\mathbf{0 . 5 4 6 2}$ & $\mathbf{3}(\mathbf{2 . 7})$ \\
$\mathbf{3}$ & $\mathbf{7 2}$ & $\mathbf{1 8 2 5}$ & $\mathbf{1 9 0 9}$ & $\mathbf{0 . 0 3 5 1}$ & $\mathbf{0 . 0 0 0 1}$ & $\mathbf{0 . 0 0 1 6}$ & $\mathbf{0 . 5 4 6 1}$ & $\mathbf{2}^{\mathbf{0}}(\mathbf{2 . 8})$ \\
4 & 63 & 1990 & 1883 & 0.0369 & 0.0009 & 0.0047 & 0.5480 & $3(2.9)$ \\
$* * * * * * * *$ Difference & w.r.t. the value of year -2 significant at $1 \%, 5 \%, 10 \%$ levels & & \\
\hline
\end{tabular}

ooo,oo,o: Change w.r.t. the value of year -2 greater for RI plan adopters than for matching firms at $1 \%, 5 \%, 10 \%$ levels. 
Table 3

Segment Statistics Around RI Plan Adoptions by Multi-Divisional Firms

Median levels presented. Assets, Sales in constant 2002 dollars. Reldif provides the relative difference in years with respect to RI plan adoption. ROA equals Segment Operating Earnings divided by Segment Assets. Invest/A, IInvest/A, and Cash/A indicate Segment Investment, Industry-adjusted Segment Investment, and Cash Flows normalized by Segment Assets. Industry-adjusted Segment Investment is computed as the difference between Segment Investment and the median Segment Investment of all single-segment firms operating in the same industry. Cash Flows equal Segment Operating Earnings plus Depreciation.

\begin{tabular}{|c|c|c|c|c|c|c|c|}
\hline \multicolumn{8}{|l|}{ Adopters: } \\
\hline reldif & ROA & Invest/A & I-Invest/A & Cash/A & Sales & Assets & Nobs \\
\hline-4 & 0.1196 & 0.0583 & 0.0123 & 0.1800 & 574 & 398 & 225 \\
\hline-3 & 0.1101 & 0.0588 & 0.0117 & 0.1662 & 566 & 403 & 219 \\
\hline-2 & 0.1103 & 0.0531 & 0.0090 & 0.1629 & 593 & 381 & 230 \\
\hline-1 & 0.1206 & 0.0528 & 0.0058 & 0.1728 & 527 & 336 & 238 \\
\hline 0 & 0.1295 & 0.0540 & 0.0077 & 0.1829 & 525 & 355 & 262 \\
\hline 1 & 0.1337 & 0.0506 & 0.0077 & 0.1884 & 566 & 471 & 241 \\
\hline 2 & $0.1325^{* *}$ & 0.0507 & 0.0072 & $0.1799^{*}$ & 578 & 459 & 233 \\
\hline 3 & $0.1316^{* *}$ & $0.0478^{* *}$ & $0.0058^{* * *}$ & $0.1851^{* *}$ & 514 & 360 & 222 \\
\hline 4 & 0.1252 & 0.0508 & 0.0084 & 0.1728 & 585 & 491 & 196 \\
\hline \multicolumn{8}{|c|}{ Matching firms: } \\
\hline reldif & ROA & Invest/A & I-Invest/A & Cash/A & Sales & Assets & Nobs \\
\hline-4 & 0.1251 & 0.0578 & 0.0156 & 0.1753 & 435 & 329 & 237 \\
\hline-3 & 0.1182 & 0.0524 & 0.0127 & 0.1799 & 440 & 317 & 212 \\
\hline-2 & 0.1202 & 0.0563 & 0.0119 & 0.1753 & 436 & 329 & 237 \\
\hline-1 & 0.1123 & 0.0552 & 0.0142 & 0.1681 & 375 & 288 & 239 \\
\hline 0 & 0.1108 & 0.0531 & 0.0090 & 0.1776 & 363 & 303 & 265 \\
\hline 1 & 0.1215 & 0.0563 & 0.0117 & 0.1751 & 368 & 314 & 234 \\
\hline 2 & 0.1175 & $0.0488^{* *,, o o}$ & $0.0057^{* *, 0}$ & 0.1712 & 434 & 386 & 207 \\
\hline 3 & $0.1201^{\circ}$ & $0.0452^{* *}$ & $0.0050^{* *}$ & $0.1672^{\circ}$ & 416 & 353 & 191 \\
\hline 4 & 0.1144 & 0.0483 & 0.0099 & 0.1707 & 431 & 387 & 165 \\
\hline
\end{tabular}


Table 4

Segment Investment and Performance around RI Plan Adoptions by Multi-Divisional Firms

Median levels presented. Reldif provides the relative difference in years with respect to RI plan adoption. Segment's industry $q$ is equal to the median Tobin's $\mathrm{Q}$ of all single-segment firms in the same industry. Invest/A, I-Invest/A, and Cash/A indicate Segment Investment, Industry-adjusted Segment Investment, and Cash Flows normalized by Segment Assets. Industry-adjusted Segment Investment is computed as the difference between Segment Investment and the median Segment Investment of all single-segment firms operating in the same industry. Cash Flows equal Segment Operating Earnings plus Depreciation. "Indust. $q$ " denotes industry $q$ of the segment.

Panel A: Segment's industry q below firm's weighted $q$

\begin{tabular}{rrrrrrrrr}
\multicolumn{1}{c}{ Adopters: } & \multicolumn{1}{c}{ Matching Firms: } \\
reldif & \multicolumn{1}{c}{ Invest/A } & I-Invest/A & \multicolumn{1}{c}{ Cash/A } & Indust. $q$ & Invest/A & I-Invest/A & \multicolumn{1}{c}{ Cash/A } & Indust. $q$ \\
-4 & 0.0527 & 0.0101 & 0.1887 & 1.15 & 0.0557 & 0.0109 & 0.1665 & 1.17 \\
-3 & 0.0516 & 0.0115 & 0.1677 & 1.20 & 0.0491 & 0.0069 & 0.1874 & 1.17 \\
$-\mathbf{- 2}$ & $\mathbf{0 . 0 5 0 4}$ & $\mathbf{0 . 0 1 1 8}$ & $\mathbf{0 . 1 6 1 9}$ & $\mathbf{1 . 2 5}$ & $\mathbf{0 . 0 5 1 4}$ & $\mathbf{0 . 0 0 8 2}$ & $\mathbf{0 . 1 7 3 8}$ & $\mathbf{1 . 2 3}$ \\
-1 & 0.0503 & 0.0076 & 0.1671 & 1.26 & 0.0547 & 0.0133 & 0.1579 & 1.28 \\
0 & 0.0521 & 0.0072 & 0.1891 & 1.33 & 0.0493 & 0.0084 & 0.1763 & 1.29 \\
1 & 0.0553 & 0.0103 & 0.1960 & 1.33 & 0.0556 & 0.0078 & 0.1798 & 1.28 \\
$\mathbf{2}$ & $\mathbf{0 . 0 5 6 5}$ & $\mathbf{0 . 0 0 7 1}$ & $\mathbf{0 . 1 7 3 6}$ & $\mathbf{1 . 2 6}$ & $\mathbf{0 . 0 4 8 5}$ & $\mathbf{0 . 0 1 0 4}$ & $\mathbf{0 . 1 8 0 2}$ & $\mathbf{1 . 2 4}$ \\
$\mathbf{3}$ & $\mathbf{0 . 0 4 9 5}$ & $\mathbf{0 . 0 0 2 0}$ & $\mathbf{0 . 1 8 6 2}$ & $\mathbf{1 . 2 6}$ & $\mathbf{0 . 0 5 0 9}$ & $\mathbf{0 . 0 1 1 0}$ & $\mathbf{0 . 1 8 4 5}$ & $\mathbf{1 . 2 8}$ \\
4 & 0.0480 & 0.0071 & 0.1801 & 1.19 & 0.0474 & 0.0093 & 0.1792 & 1.19
\end{tabular}

Panel B: Segment's industry q above firm's weighted $q$

\begin{tabular}{|c|c|c|c|c|c|c|c|c|}
\hline \multirow[b]{2}{*}{ reldif } & \multicolumn{4}{|l|}{ Adopters: } & \multicolumn{4}{|c|}{ Matching Firms: } \\
\hline & Invest/A & I-Invest/A & Cash/A & Indust. $q$ & Invest/A & I-Invest/A & Cash/A & Indust. $q$ \\
\hline-4 & 0.0629 & 0.0131 & 0.1722 & 1.48 & 0.0672 & 0.0172 & 0.1974 & 1.44 \\
\hline-3 & 0.0615 & 0.0136 & 0.1633 & 1.51 & 0.0605 & 0.0141 & 0.1755 & 1.54 \\
\hline-2 & 0.0559 & 0.0024 & 0.1655 & 1.63 & 0.0651 & 0.0149 & 0.1767 & 1.53 \\
\hline-1 & 0.0550 & 0.0025 & 0.1913 & 1.72 & 0.0570 & 0.0148 & 0.1729 & 1.73 \\
\hline 0 & 0.0568 & 0.0108 & 0.1802 & 1.79 & 0.0575 & 0.0108 & 0.1780 & 1.70 \\
\hline 1 & 0.0481 & 0.0058 & 0.1707 & 1.76 & 0.0588 & 0.0177 & 0.1730 & 1.67 \\
\hline 2 & 0.0477 & 0.0072 & $0.1917^{*}$ & 1.70 & $0.0488^{* *, 0}$ & $0.0044^{* * * *}$ & 0.1667 & 1.77 \\
\hline 3 & 0.0516 & 0.0091 & $0.1861^{*}$ & 1.72 & $0.0452^{* * * *}$ & $0.0015^{* * * *}$ & 0.1603 & 1.59 \\
\hline 4 & 0.0595 & 0.0116 & 0.1718 & 1.58 & 0.0518 & 0.0105 & 0.1798 & 1.64 \\
\hline
\end{tabular}


Table 5

Probit Analysis of RI Plan Adoptions

The table presents the Probit analysis of RI plan adoption decisions. Models 1-5 are based on 114,074 firm-year observations, models 6-8 are based on 16,463 firmyear observations with available CEO compensation data, and model 9 is based on 16,903 firm-year observations with available governance-quality (G-index) data. The dependent variable is a dummy variable equal to one if a firm adopted RI plan in a given year. Industry-adjusted Investment is computed as the weighted average of segment investments adjusted for the median investment ratio in the segment's industry. Industry Growth Opportunities measured as the weighted average of industry $q$ 's of all company's segments. Segment Diversity is the ratio of the firm's standard deviation of segment asset-weighted $q$ 's to the equally-weighted average $q$ of firm's segments, as defined by Rajan et. al (2000). Investment Efficiency is the correlation between segment growth opportunities measured by $q$ 's and industry-adjusted segment investment, called "the relative value added by allocation" by Rajan et. al (2000). CEO bonus compensation and CEO (percentage) share ownership are gathered from Execucomp database. G-Index is the Gompers et al. (2003) index gathered from the Risk Metrics database.T-statistics are in italics below the coefficient estimates.

\begin{tabular}{|c|c|c|c|c|c|c|c|c|c|}
\hline Explanatory Variables: & 1 & 2 & 3 & 4 & 5 & 6 & 7 & 8 & 9 \\
\hline \multirow[t]{2}{*}{ Log(Total Assets) } & 0.1025 & 0.1087 & 0.1085 & 0.1083 & 0.1012 & -0.0622 & -0.0663 & -0.0984 & 0.0148 \\
\hline & $8.70^{* * * *}$ & $9.00^{* * * *}$ & $8.94^{* * *}$ & $8.94^{* * *}$ & $8.12^{* * * *}$ & $-3.00^{* * * *}$ & $-3.09^{* * *}$ & $-4.24^{* * *}$ & 0.57 \\
\hline \multirow[t]{2}{*}{ Weighted segment ROA } & 1.0292 & 1.1465 & 1.1521 & 1.1534 & 1.2251 & 0.5908 & 0.7922 & 0.8965 & 1.2211 \\
\hline & $6.06^{* * *}$ & $6.23^{* * *}$ & $6.16^{* * *}$ & $6.16^{* * *}$ & $5.88^{* * * *}$ & $2.59^{* * *}$ & $3.09^{* * *}$ & $3.06^{* * *}$ & $3.35^{* * * *}$ \\
\hline \multirow[t]{2}{*}{ Herfindahl Index } & -0.3190 & -0.3536 & -0.3530 & -0.3265 & -0.2752 & -0.3587 & -0.3243 & -0.2297 & -0.3022 \\
\hline & $-3.27^{* * * *}$ & $-3.60^{* * * *}$ & $-3.59^{* * * *}$ & $-2.99^{* * * * *}$ & $-2.49^{* * *}$ & $-3.12^{* * * * *}$ & $-2.51^{* * *}$ & $-1.78^{*}$ & $-2.08^{* * *}$ \\
\hline \multirow[t]{2}{*}{ Ind.-adj. Investment/Assets } & & -0.8483 & -0.8514 & -0.8487 & -1.0816 & & -1.3880 & -1.6532 & -0.9962 \\
\hline & & $-1.84^{*}$ & $-1.85^{*}$ & $-1.84^{*}$ & $-2.28^{* *}$ & & $-2.28^{* *}$ & $-2.66^{* * *}$ & -1.18 \\
\hline \multirow{2}{*}{ Industry Growth Opportunities } & & & -0.0071 & -0.0135 & 0.0340 & & -0.1283 & -0.0186 & 0.0091 \\
\hline & & & 0.20 & 0.35 & 0.82 & & $-2.52^{* * *}$ & -0.36 & 0.14 \\
\hline \multirow[t]{2}{*}{ Segment Diversity } & & & & 0.0969 & 0.0289 & & 0.1131 & -0.0140 & 0.1282 \\
\hline & & & & 0.55 & 0.17 & & 0.54 & 0.10 & 0.62 \\
\hline \multirow{2}{*}{ Investment Efficiency } & & & & 1.2632 & 1.5433 & & 1.6276 & 2.2600 & 0.8353 \\
\hline & & & & 0.41 & 0.49 & & 0.39 & 0.52 & 0.20 \\
\hline \multirow[t]{2}{*}{ Total Cash/ Total Assets } & & & & & -1.6229 & & & -1.8728 & -1.3035 \\
\hline & & & & & $-5.15^{* * *}$ & & & $-5.04^{* * *}$ & $-2.77^{* * *}$ \\
\hline \multirow[t]{2}{*}{ Total Debt/ Total Assets } & & & & & -0.5122 & & & 0.0210 & -0.1167 \\
\hline & & & & & $-3.77^{* * *}$ & & & 0.10 & -0.56 \\
\hline \multirow[t]{2}{*}{ CEO Bonus/ Tot. Compensation } & & & & & & 0.1241 & 0.0756 & 0.0823 & \\
\hline & & & & & & 0.71 & 0.42 & 0.45 & \\
\hline \multirow[t]{2}{*}{ CEO Share Ownership } & & & & & & -1.1437 & -1.0688 & -0.9347 & \\
\hline & & & & & & $-2.16^{* *}$ & $-2.02^{* *}$ & $-1.73^{*}$ & \\
\hline \multirow[t]{2}{*}{ G-Index } & & & & & & & & & 0.0293 \\
\hline & & & & & & & & & $2.21^{* * *}$ \\
\hline Correctly predicted & $68 \%$ & $69 \%$ & $69 \%$ & $69 \%$ & $70 \%$ & $68 \%$ & $66 \%$ & $64 \%$ & $60 \%$ \\
\hline Pseudo $\mathrm{R}^{2}$ & 0.11 & 0.12 & 0.12 & 0.12 & 0.14 & 0.30 & 0.31 & 0.33 & 0.08 \\
\hline
\end{tabular}

$* * *, * *, *$ denotes statistical significance at $1 \%, 5 \%$, and $10 \%$ levels, respectively. 
Table 6

Segment Investment Analysis (2-way Fixed Effects)

Dependent variable is the Segment Investment normalized by segment assets. "Segment Growth Opportunities" are measured by the median Tobin's Q of all focused firms in segment's industry. "Post-adoption" is a dummy variable equal to one for years following RI plan adoption both for the adopter and its matching firm. "Adopter" is a dummy variable equal to one for RI plan adopters. "Other Segments' Growth Opportunities" are equal to the weighted average of other segments' industry q's. "Segment's Cash Flows" are measured as the sum of Segment's Operating Earnings and Segment Depreciation. "Other Segments' Cash Flows" is the sum of Cash Flows generated by other segments. "CEO turnover" is a dummy variable equal to one if the adopter appoints a new CEO within one year window around the plan implementation. T-statistics below the coefficient estimates. Firm and annual fixed effects not reported.

\begin{tabular}{|c|c|c|c|c|}
\hline Model & 1 & 2 & 3 & 4 \\
\hline Sample & Full & Full & $\begin{array}{l}\text { Expect. Adopter } \\
\text { and Unexpect. } \\
\text { Nonadopter }\end{array}$ & Full \\
\hline \multicolumn{5}{|l|}{ Explanatory Variables: } \\
\hline \multirow[t]{2}{*}{ Segment's Growth Opportunities } & 0.0021 & -0.0014 & -0.0019 & -0.0014 \\
\hline & 0.96 & -0.71 & -0.58 & -0.51 \\
\hline \multirow[t]{2}{*}{$\begin{array}{l}\text { Segment's Growth Opportunities } \\
\text { * Adopter*Post-adoption }\end{array}$} & & 0.0094 & 0.0098 & 0.0097 \\
\hline & & $2.37^{* *}$ & $2.37^{* * *}$ & $2.05^{* *}$ \\
\hline \multirow[t]{2}{*}{$\begin{array}{l}\text { Other Segments' Growth } \\
\text { Opportunities }\end{array}$} & -0.0011 & -0.0011 & -0.0032 & -0.0011 \\
\hline & -0.36 & -0.39 & -0.98 & -0.37 \\
\hline \multirow{2}{*}{ Segment's Cash Flows/Assets } & 0.0180 & 0.0201 & 0.0343 & 0.0190 \\
\hline & $2.83^{* * * *}$ & $3.19^{* * * *}$ & $5.05^{* * *}$ & $2.99^{* * * *}$ \\
\hline \multirow{2}{*}{ Other Segments' Cash Flows/Assets } & 0.0002 & 0.0001 & 0.0002 & 0.0001 \\
\hline & $6.34^{* * * *}$ & $4.99^{* * * *}$ & $5.94^{* * * *}$ & $4.99^{* * *}$ \\
\hline \multirow[t]{2}{*}{$\begin{array}{l}\text { Other Segments' Cash } \\
\text { Flows/Assets* Adopter*Post- } \\
\text { adoption }\end{array}$} & & 0.0011 & 0.0009 & 0.0009 \\
\hline & & $6.93^{* * *}$ & $\mathbf{4 . 1 8}^{* * * *}$ & $4.59^{* * * *}$ \\
\hline \multirow{2}{*}{ Post-Adoption } & & -0.0024 & 0.0025 & -0.0025 \\
\hline & & -0.32 & 0.30 & -0.33 \\
\hline \multirow[t]{2}{*}{ Adopter*Post Adoption } & & -0.0188 & -0.0199 & -0.0196 \\
\hline & & $-2.36^{* * *}$ & $-2.35^{* *}$ & $-2.10^{* * *}$ \\
\hline \multirow[t]{2}{*}{$\begin{array}{l}\text { Segment's Growth Opportunities } \\
{ }^{*} \text { CEO Turnover*Post-adoption }\end{array}$} & & & & -0.0005 \\
\hline & & & & 0.10 \\
\hline \multirow{2}{*}{$\begin{array}{l}\text { Other Segments' Cash } \\
\text { Flows/Assets* CEO Turnover* } \\
\text { Adopter*Post-adoption }\end{array}$} & & & & \\
\hline & & & & $\begin{array}{r}0.0005 \\
1.69^{*}\end{array}$ \\
\hline \multirow[t]{3}{*}{ CEO turnover*Post -Adoption } & & & & 0.0019 \\
\hline & & & & 0.14 \\
\hline & & & & \\
\hline
\end{tabular}

$* * *, * *, *$ denotes statistical significance at $1 \%, 5 \%$, and $10 \%$ levels, respectively. 
Table 7

Investment Efficiency Analysis (2-way Fixed Effects)

Dependent variable, Investment Efficiency, is the correlation between segment growth opportunities measured by $q$ 's and industry-adjusted segment investment, called "the relative value added by allocation" by Rajan et. al (2000), multiplied by 100 in order to obtain regression coefficients with larger absolute values. Segment Diversity is the ratio of the firm's standard deviation of segment asset-weighted $q$ 's to the equally-weighted average $q$ of firm's segments, as defined by Rajan et. al (2000). "Post-adoption" is a dummy variable equal to one for years following RI plan adoption both for the adopter and its matching firm. "Adopter" is a dummy variable equal to one for RI plan adopters. "Related Segments" is a dummy variable equal to one if all firm's segments share the same 3-digit SIC code. "CEO turnover" is a dummy variable equal to one if the adopter appoints a new CEO within one year window around the plan implementation. T-statistics below the coefficient estimates. Firm and annual fixed effects not reported.

\begin{abstract}
Model:
\end{abstract}
Sample

$\log ($ Sales $)$

1 / Equally weighted average of seg. q's

Segment Diversity

Segment Diversity * Post-adoption

\section{Segment Diversity * Post-adoption* Adopter}

Segment Diversity * Post-adoption*CEO Turnover

Post-adoption

\section{Post-adoption* Adopter}

Post-adoption* Adopter*Related Segments$$
1
$$

Full Sample

$-0.2372$

$-2.96^{* * *}$

$-0.2695$

$-0.83$

\section{$-1.6766$}

$-3.58^{* * * *}$

$-0.2375$

$-2.97^{* * *}$

$-0.3199$

$-0.98$

$-1.4434$

$-2.39^{* *}$

$-1.5120$

$-1.86^{*}$

2.2670

$3^{2.23 * * *}$

1.5881

$2.64^{* * * *}$

4

5

Exp. Adopt and Unexp. Nonadopt.

$-2.91^{* * * *}$

$-0.2618$

$-0.81$

$-2.0883$

$-4.21^{* * *}$

$-0.2600$

$-2.91^{* * *}$

$-0.5307$

$-1.38$

$-1.7703$

$-3.36^{* * *}$

-1.6
-3.996

$-3.97^{\text {**** }}$

4.0109

$4.93^{* * * *}$

1.9940

$3.10^{* * *}$

$-0.0973$

$-0.55$

0.2457

$2.31^{* *}$
$-0.0729$

0.17

$-0.42$

$-0.1479$

$-0.74$

0.2638

$2.18^{* * *}$

0.1281

0.63

$-0.1559$

$-0.81$
8

Full Sample

\section{Fun}

$-2.95^{* * *}$

$-0.3232$

$-1.00$

$-1.4325$

$-2.37^{* *}$

$-1.5358$

$-1.89^{*}$

2.0952

2.80 ****

0.7619

0.67

0.0315

0.17

$-0.56$

0.2472

$2.19^{\text {*** }}$

$-0.0072$

$-0.10$

Post-adoption*CEO Turnover 
Table 8

Diversification Discount Analysis (2-way Fixed Effects)

Dependent Variable is Excess Value $=\ln ($ Market Value of Assets/ Imputed Value). Market Value of Assets is computed as Market Value of Equity + Total Assets - Book Value of Equity. The Imputed Value of a firm is calculated as a sum of imputed values of its segments. To compute imputed value of a segment, we multiply its Sales (Assets) by the Sales (Assets) Multiple (median 'Market Value of Assets'-to-Sales (Assets) ratio of all single-divisional firms in the segment's industry). Herfindahl Index is equal to the sum of squared divisional proportions of company's sales. "Post-adoption" is a dummy variable equal to one for years following RI plan adoption both for the adopter and its matching firm. "Adopter" is a dummy variable equal to one for RI plan adopters. "Related Segments" is a dummy variable equal to one if all firm's segments share the same 3-digit SIC code. Segment Diversity is the ratio of the firm's standard deviation of segment asset-weighted $q$ 's to the equally-weighted average $q$ of firm's segments, as defined by Rajan et. al (2000). Investment Efficiency equals to the correlation between segment growth opportunities measured by $q$ 's and industry-adjusted segment investment, called "the relative value added by allocation" by Rajan et. al (2000), multiplied by a factor of 100. "CEO turnover" is a dummy variable equal to one if the RI plan adopter appoints a new CEO within one year window around the plan implementation. T-statistics below the coefficient estimates. Firm and annual fixed effects not reported.

\begin{tabular}{|c|c|c|c|c|c|c|c|c|c|c|}
\hline Model & 1 & 2 & 3 & 4 & 5 & 6 & 7 & 8 & 9 & 10 \\
\hline Sample & \multicolumn{4}{|c|}{ Full Sample } & \multicolumn{4}{|c|}{ Expected Adopters and Unexpected Non-Adopters } & \multicolumn{2}{|c|}{ Full Sample } \\
\hline & & & & & & & & & & \\
\hline Log (Assets) & $\begin{array}{l}-0.1257 \\
(-6.00)^{* * *}\end{array}$ & $\begin{array}{l}-0.1228 \\
(-5.77)^{* * *}\end{array}$ & $\begin{array}{l}-0.1631 \\
(-7.66)^{* * * *}\end{array}$ & $\begin{array}{l}-0.1612 \\
(-7.67)^{* * * *}\end{array}$ & $\begin{array}{l}-0.1207 \\
(-4.81)^{* * *}\end{array}$ & $\begin{array}{l}-0.1279 \\
(-5.06)^{* * * *}\end{array}$ & $\begin{array}{l}-0.1537 \\
(-5.85)^{* * *}\end{array}$ & $\begin{array}{l}-0.1541 \\
(-5.91)^{* * *}\end{array}$ & $\begin{array}{l}-0.1253 \\
(-5.93)^{* * *}\end{array}$ & $\begin{array}{l}-0.1274 \\
(-5.98)^{* * *}\end{array}$ \\
\hline Herfindahl Index & $\begin{array}{c}0.2608 \\
(4.63)^{* * *} \\
\end{array}$ & $\begin{array}{c}0.2608 \\
(4.54)^{* * * *}\end{array}$ & & & $\begin{array}{l}0.1561 \\
(2.27)^{* *} \\
\end{array}$ & $\begin{array}{l}0.1326 \\
(1.92)^{*}\end{array}$ & & & $\begin{array}{c}0.2616 \\
(4.62)^{* * *}\end{array}$ & $\begin{array}{c}0.2560 \\
(4.46)^{* * * *} \\
\end{array}$ \\
\hline Post-adoption & $\begin{array}{c}-0.0246 \\
(-0.50)\end{array}$ & & $\begin{array}{c}-0.0035 \\
(-0.10)\end{array}$ & & $\begin{array}{c}-0.0160 \\
(-0.26)\end{array}$ & & $\begin{array}{c}0.0114 \\
(0.20)\end{array}$ & & $\begin{array}{c}-0.0246 \\
(-0.50)\end{array}$ & $\begin{array}{c}-0.0246 \\
(-0.50)\end{array}$ \\
\hline $\begin{array}{l}\text { Post-adoption } \\
\text { * Adopter }\end{array}$ & $\begin{array}{l}\mathbf{0 . 0 6 8 0} \\
(2.25)^{* * *}\end{array}$ & & $\begin{array}{l}\text { 0.0579 } \\
(1.99)^{* * *}\end{array}$ & & $\begin{array}{c}\text { 0.1108 } \\
(\mathbf{3 . 0 5})^{* * * *}\end{array}$ & & $\begin{array}{c}\mathbf{0 . 0 9 8 3} \\
(\mathbf{2 . 8 4})^{* * * *}\end{array}$ & & $\begin{array}{l}0.0659 \\
(1.98)^{* *}\end{array}$ & $\begin{array}{l}\text { 0.0739 } \\
(2.23)^{* * *}\end{array}$ \\
\hline $\begin{array}{l}\text { Post-adoption* } \\
\text { Adopter*Related Segments }\end{array}$ & & & & & & & & & & $\begin{array}{c}-0.0205 \\
(-0.44) \\
\end{array}$ \\
\hline Segment Diversity & & & $\begin{array}{c}-1.1484 \\
(-10.41)^{* * *}\end{array}$ & $\begin{array}{c}-1.3348 \\
(-11.31)^{* * *}\end{array}$ & & & $\begin{array}{l}-1.0622 \\
(-8.12)^{* * *}\end{array}$ & $\begin{array}{l}-1.2352 \\
(-8.72)^{* * *}\end{array}$ & & \\
\hline $\begin{array}{l}\text { Segment Diversity* } \\
\text { Post-adoption* Adopter }\end{array}$ & & & & $\begin{array}{c}0.6452 \\
(4.03)^{* * * *}\end{array}$ & & & & $\begin{array}{c}\mathbf{0 . 5 8 8 8} \\
(3.29)^{* * * *}\end{array}$ & & \\
\hline Investment Efficiency & & $\begin{array}{l}0.1866 \\
(3.52)^{* * *}\end{array}$ & & & & $\begin{array}{l}0.1881 \\
(2.97)^{* * *}\end{array}$ & & & & \\
\hline Post-adoption*CEO Turnover & & & & & & & & & $\begin{array}{c}0.0062 \\
(0.14)\end{array}$ & \\
\hline $\mathrm{N}$ & 877 & 877 & 877 & 877 & 642 & 642 & 642 & 642 & 877 & 877 \\
\hline
\end{tabular}

$* * *, * * *$ denotes statistical significance at $1 \%, 5 \%$, and $10 \%$ levels, respectively. 
Table 9

Tobin's Q Changes, Diversification, and RI Plan Adoptions (2-way fixed effects)

Dependent variable is Tobin's Q. T-statistics below coefficient estimates. Industry growth opportunities measured as the weighted average of industry q's of all company's segments. Herfindahl Index is equal to the sum of squared divisional proportions of company's sales. Post-adoption is a dummy variable equal to one for years following plan adoption both for the adopter and its matching firm. "Adopter" is a dummy variable equal to one for RI plan adopters. T-statistics below the coefficient estimates. Firm and annual fixed effects not reported.

\begin{tabular}{|c|c|c|c|c|}
\hline & \multicolumn{2}{|c|}{ Diversified Adopters } & \multicolumn{2}{|c|}{ Single-segment Adopters } \\
\hline Explanatory variables & 1 & 2 & 3 & 4 \\
\hline Log (Sales) & -0.0253 & -0.0293 & -0.3099 & -0.2899 \\
\hline & $(-0.79)$ & $(-0.91)$ & $\left(-5.35^{* * *}\right)$ & $\left(-4.86^{* * *}\right)$ \\
\hline Industry growth opportunities & 0.1230 & 0.1239 & 0.2156 & 0.2100 \\
\hline & $\left(3.38^{* * *}\right)$ & $\left(3.45^{* * *}\right)$ & $\left(3.49^{* * *}\right)$ & $\left(3.39^{* * *}\right)$ \\
\hline Herfindahl Index & 0.2989 & 0.3505 & & 0.3219 \\
\hline & $\left(3.05^{* * *}\right)$ & $\left(3.69^{* * * *}\right)$ & & $(1.42)$ \\
\hline Weighted segment ROA & & 1.7506 & 2.5359 & 2.5194 \\
\hline & & $\left(10.35^{* * *}\right)$ & $\left(7.21^{* * *}\right)$ & $\left(7.16^{* * *}\right)$ \\
\hline Post-adoption & 0.0502 & 0.0202 & -0.0397 & -0.0408 \\
\hline & $(0.58)$ & $(0.24)$ & $(-0.20)$ & $(-0.20)$ \\
\hline Post-adoption*Adopter & 0.1082 & 0.1127 & -0.0109 & -0.0162 \\
\hline & $\left(2.07^{* *}\right)$ & $\left(2.20^{* *}\right)$ & $(-0.10)$ & $(-0.14)$ \\
\hline
\end{tabular}

$* * *, * * *$ denotes statistical significance at $1 \%, 5 \%$, and $10 \%$ levels, respectively. 
Table 10

Probit Analysis of RI Plan Eliminations

The table presents the Probit analysis of RI plan elimination decisions. The dependent variable is a dummy variable equal to one if a previous adopter did not use RI plan during the particular year (starting from the year after adoption until 2009). Return on Assets is measured as EBIT/Assets. Herfindahl index is the sum of squared divisional sales weights. M/B of Assets is measured as [MV of Equity + Total Assets - BV of Equity] / Total Assets. New CEO is a dummy if the CEO if the company was different from the one who was with the company during the adoption year. CEO bonus compensation and CEO (percentage) share ownership are gathered from Execuсотр database. G-Index is the Gompers et al. (2003) index gathered from the Risk Metrics database. T-statistics are in italics below the coefficient estimates.

\begin{tabular}{|c|c|c|c|c|}
\hline & 1 & 2 & 3 & 4 \\
\hline Explanatory Variables: & & & & \\
\hline Log(Total Assets) & $\begin{array}{l}0.1389 \\
3.46^{* * *}\end{array}$ & $\begin{array}{l}0.1409 \\
3.50^{* * * *}\end{array}$ & $\begin{array}{l}0.1403 \\
3.46^{* * *}\end{array}$ & $\begin{array}{l}0.1010 \\
2.28^{* * *}\end{array}$ \\
\hline Return on Assets & $\begin{array}{l}-3.3238 \\
-3.83^{* * * *}\end{array}$ & $\begin{array}{l}-3.3333 \\
-3.84^{* * *}\end{array}$ & $\begin{array}{l}-2.8372 \\
-3.21^{* * *}\end{array}$ & $\begin{array}{l}-3.9883 \\
-3.94^{* * *}\end{array}$ \\
\hline Herfindahl Index & $\begin{array}{l}1.0539 \\
5.06^{* * *}\end{array}$ & $\begin{array}{l}1.0435 \\
4.99^{* * *}\end{array}$ & $\begin{array}{l}1.0577 \\
5.04^{* * * *}\end{array}$ & $\begin{array}{l}0.9905 \\
4.47^{* * * *}\end{array}$ \\
\hline Capex/Assets & $\begin{array}{l}-6.3487 \\
-4.08^{* * *}\end{array}$ & $\begin{array}{l}-6.4121 \\
-4.12^{* * *}\end{array}$ & $\begin{array}{l}-6.6519 \\
-4.25^{* * * *}\end{array}$ & $\begin{array}{l}-5.8843 \\
-3.72^{* * * *}\end{array}$ \\
\hline $\mathrm{M} / \mathrm{B}$ of Assets & $\begin{array}{l}0.0014 \\
0.10\end{array}$ & $\begin{array}{l}0.0014 \\
0.10\end{array}$ & $\begin{array}{l}0.0006 \\
0.00\end{array}$ & $\begin{array}{l}0.0142 \\
1.03\end{array}$ \\
\hline Total Cash/ Total Assets & $\begin{array}{l}1.0382 \\
1.41\end{array}$ & $\begin{array}{l}1.0271 \\
1.40\end{array}$ & $\begin{array}{l}0.9392 \\
1.26\end{array}$ & $\begin{array}{l}1.2351 \\
1.56\end{array}$ \\
\hline Total Debt/ Total Assets & $\begin{array}{l}-1.4046 \\
-3.36 \text { *** }\end{array}$ & $\begin{array}{l}-1.4110 \\
-3.37^{* * *}\end{array}$ & $\begin{array}{l}-1.4038 \\
-3.35^{* * * *}\end{array}$ & $\begin{array}{l}-1.3807 \\
-2.97^{* * * *}\end{array}$ \\
\hline New CEO & & $\begin{array}{l}0.1780 \\
0.89\end{array}$ & $\begin{array}{l}0.1699 \\
0.84\end{array}$ & \\
\hline CEO Bonus/ Tot. Compensation & & & $\begin{array}{l}-1.0059 \\
-2.91^{* * * *}\end{array}$ & \\
\hline CEO Share Ownership & & & $\begin{array}{l}0.0015 \\
0.00\end{array}$ & \\
\hline G-Index & & & & $\begin{array}{l}-0.0078 \\
-0.33 \\
\end{array}$ \\
\hline Pseudo $\mathrm{R}^{2}$ & 0.08 & 0.09 & 0.10 & 0.08 \\
\hline $\mathrm{N}$ & 840 & 840 & 840 & 753 \\
\hline
\end{tabular}

$* * *, * *, *$ denotes statistical significance at $1 \%, 5 \%$, and $10 \%$ levels, respectively. 